$\begin{array}{r}\text { Uludağ Üniversitesi Ĕgitim Fakültesi Dergisi } \\ \text { Journal of Uludag University Faculty of Education } \\ \text { e-ISSN: 2667-6788 } \\ 2021 ; 34(\text { Özel Say1); 185-239 } \\ \text { https://dergipark.org.tr/tr/pub/uefad } \\ \hline\end{array}$

YARATICI DRAMA YÖNTEMININ ZIIHINSEL YETERSIZLLIĞİ OLAN ÖĞRENCILLERIN OKUDUĞUNU ANLAMA BECERILLERİ ÜZERINDEKİ ETKISİ

\title{
Şenay ARSLAN SOYALTIN ${ }^{1}$, İbrahim Halil DİKEN² ${ }^{2}$ Ömer ADIGÜZEL ${ }^{3}$
}

\begin{tabular}{|c|c|}
\hline Makale Bilgisi & Özet \\
\hline Araştırma Makalesi & \multirow{6}{*}{$\begin{array}{l}\text { Bu araştırmada, yaratıcı drama yöntemi ile yapılandırılan öğretim programının hafif } \\
\text { düzeyde zihinsel yetersizliği olan öğrencilerin okuduğunu anlama becerileri üzerindek } \\
\text { etkisi incelenmiştir. Araştırmada eşleştirmeli ön test - son test kontrol gruplu desen } \\
\text { kullanılmıştır. Araştırmanın deney ve kontrol grubunu, Ankara ili içerisinde bulunan bir } \\
\text { rehabilitasyon merkezinde eğitim gören, araştırma için ön koşul becerilerine sahip } \\
\text { öğrenci oluşturmaktadır. Deney grubuna yaratıc drama yöntemiyle hazırlanan } \\
\text { Okuduğunu Anlama Becerileri Öğretim Programı (OABÖP) uygulanmıştır. Verilerin } \\
\text { analizinde SPSS programı kullanılmıştır. Araştırmada deney grubuna katılan ögrencilerin } \\
\text { okuma becerilerinin, geleneksel yöntemle yapılan okuma programından daha fazla } \\
\text { geliştiğini göstermektedir. Deney grubu OABÖP'ye katıllımı sonrasında metinlere ilişkin } \\
\text { okuduğunu anlama sorularını yüksek oranda bağımsız yanıtlamışıtır. Oyunlarla metinlerde } \\
\text { işlenen konuların bağlantılı olması öğrenmede kalıcıllğ̆ sağlamıştır. }\end{array}$} \\
\hline DOI: $10.19171 /$ uefad.849804 & \\
\hline Makale Geçmişi: & \\
\hline 30.12 .2020 & \\
\hline 04.07 .2021 & \\
\hline $\begin{array}{l}\text { Anahtar Kelimeler: } \\
\text { Okuma, } \\
\text { Okuduğunu anlama, } \\
\text { Zihinsel yetersizlik, } \\
\text { Yaratıcı drama. }\end{array}$ & \\
\hline
\end{tabular}

\begin{tabular}{|c|c|}
\hline $\begin{array}{l}\text { THE EFFE } \\
\text { COMPREHE }\end{array}$ & $\begin{array}{l}\text { CT OF CREATIVE DRAMA METHOD ON READING } \\
\text { JSION SKILLS OF STUDENTS WITH INTELLECTUAL }\end{array}$ \\
\hline \\
\hline Article Information & Abstract \\
\hline Research Article & \multirow{6}{*}{$\begin{array}{l}\text { This quasi-experimental study investigates the effect of a program structured with creative } \\
\text { drama on the reading comprehension skills of students with mild intellectual disabilities. } \\
\text { The experimental group consisted of eight students with the necessary preconditions who } \\
\text { attended a rehabilitation center in Ankara. The sample group received Reading } \\
\text { Comprehension Skills Instruction Program. Data analyses were conducted with SPPS } \\
\text { software. Results showed that the reading skills of the students improved more } \\
\text { significantly than those receiving the classical reading programme. The experimental } \\
\text { group answered the reading comprehension questions independently in high ratios. The } \\
\text { related topics that were studied in both the games and the readings suggested that the } \\
\text { learning results were permanent. }\end{array}$} \\
\hline DOI: 10.19171/uefad.849804 & \\
\hline Article History: & \\
\hline Received $\quad 30.12 .2020$ & \\
\hline Accepted $\quad 04.07 .2021$ & \\
\hline $\begin{array}{l}\text { Keywords: } \\
\text { Reading, } \\
\text { Reading comprehension, } \\
\text { Intellectual disability, } \\
\text { Creative drama. }\end{array}$ & \\
\hline
\end{tabular}

\footnotetext{
${ }^{1}$ Blm.Uzm., Öğretmen, senayarslan_@hotmail.com., OrcID: 0000-0001-6969-7553

2 Prof. Dr., Anadolu Üniversitesi Engelliler Araştırma Enstitüsü, ihdiken@anadolu.edu.tr, OrcID: 0000-00025761-2900

3 Prof. Dr., Ankara Üniversitesi Ĕ̆itim Bilimleri Fakültesi Güzel Sanatlar Ĕ̆itimi, oadiguzel@ankara.edu.tr. OrcID: 0000-0001-9492-6231
} 
Kaynakça Gösterimi: Arslan Soyaltın, Ş., Diken, İ. H., \& Adıgüzel, Ö. (2021). Yaratıcı drama yönteminin zihinsel yetersizliği olan öğrencilerin okuduğunu anlama becerileri üzerindeki etkisi. Uludağ Üniversitesi Eğitim Fakültesi Dergisi, 34(Özel Say1), 185-239. https://doi.org/10.19171/uefad.849804

Citation Information: Arslan Soyaltın, Ş., Diken, İ. H., \& Adıgüzel, Ö. (2021). The effect of creative drama method on reading comprehension skills of students with intellectual disabilities. Journal of Uludag University Faculty of Education, 34(Special Issue), 185-239. https://doi.org/10.19171/uefad.849804

\section{GíRiş}

Ulusal okuma panelinin yüz binden fazla çalışmayı inceleyerek oluşturduğu rapora göre okuma eğitimi beş bileşenden oluşmaktadır. Bu bileşenler; sesletim, fonolojik farkındalık, akıcılık, sözcük tanıma ve anlamadır. Sesletim, öğrencilere yazılı dildeki harfler ile konuşma dilindeki tekil sesler arasındaki sistematik bağlantıları kullanmayı öğretmektedir. Seslerden sözcük oluşturma, sözcük hecelerinden sesi ayırt etme, sözcüklerden ses silme, sözcüklere ses ekleme ya da yeni bir sözcük oluşturmak için yerine bir ses koymayı içermektedir. Böylece öğrenciler sesleri tek tek birleştirerek yeni sözcük oluşturmaktadırlar. Fonolojik farkındalık, sözcükleri okuma becerisini geliştirmekte, öğrencilerin sözcükleri akıcı ve doğru olarak okumalarını, okuduklarını anlamalarını sağlamaktadır (Armbruster vd., 2001). Akıcılık, metni uygun bir hızda okumaktır. Metnin belirli bir hızda ve doğru olarak okunması okuyuculara zaman kazandırmaktadır (Akyol, 2011; Hartman vd, 2021).

Araştırmalar, iyi bir okumanın en az beş bileşenin ürünü olabileceğini göstermektedir. Bu bileşenlerin hepsi birbirlerinden bağımsız olsa bile, iyi bir okuma için en az iki bileşenin düzgün çalışması gerekmektedir. Bu bileşenler sözcük tanıma ve anlamadır. Sözcük tanıma, açıkça ya da örtülü olarak yazılı sözcüğü tanıma veya telaffuz etme yeteneğidir (Aaron, 1995). Okuduğunu anlama sürecinde önceden bir sözcük ve bilgiye sahip olmak, anlamayı kolaylaştırmaktadır. Ancak sözcük metin içinde bağımsız değildir. Öncelikle cümle içinde bir anlam kazanmakta ve anlamın parçası olmaktadır. Daha sonra cümleler paragrafı, paragraflar da metni oluşturmaktadır (Özbay, 2006). Anlama ise; metindeki kelimeleri tanımak, içindeki bilgileri almak, bağlantılar kurmak, yazarın amacını ve bakış açısını öğrenmek, verilen bilgileri 
incelemek, sorgulamak, çıkarımlar yapmak, anlamı geliştirmek, metnin yapısını keşfetmek, metni değerlendirmek gibi metinsel ve zihinsel bir dizi işlemi gerektirmektedir (Güneş, 2021, s. 25).

Okuma sürecinde amaca uygun sorular öğrencilerin okuduğunu anlama becerilerini güçlü bir şekilde desteklemektedir. Sorular öğrencilerde okumaları için amaç oluşturma, öğrencilerin dikkatini ne öğrenmeleri gerektiğine çekme, okurken öğrencilerin aktif bir şekilde düşünmelerine destek olma, öğrencilerin içeriği tekrar gözden geçirmelerine ve önceden bildikleri ile öğrendikleri yeni şeyler arasında ilişki kurmalarına yardım etmektedir (Armbruster vd., 2001).

Zihinsel yetersizliği olan öğrenciler akademik performans içerisinde, okumaya ilişkin, okumayı anlama becerilerinde de ciddi sorunlar yaşamaktadırlar (Diken \& Cavkaytar, 2007). Araştırmacılar aynı zamanda bu öğrencilerin, sesleri ayırma sorunları, fonolojik farkındalık becerilerinde yetersizlik, okuduklarını anlamada yavaşlık, bilişsel veya dilsel sınırlılıklar ya da dikkat ve davranış problemleri yaşadıklarını göstermektedir (Blachman, 1994; Brady, 1997; Tallal, 1990; Torgesen vd., 1994; Akt. Al- Otaiba \& Fuchs, 2002).

Zihinsel yetersizliği olan öğrencilerin doğru ve anlaşılır okuma ve okuduğunu anlama becerilerinde güçlük yaşadıkları (Özsoy vd., 1998) düşünüldüğünde; okuma becerisini kazanmaları için kullanılan yöntemler büyük bir önem taşımaktadır.

Ülkemizde zihinsel yetersizliği olan öğrencilere okuduğunu anlama becerilerini etkili bir şekilde kazandırmak amacıyla bazı yaklaşım, yöntem-teknik ve stratejileri konu alan araştırmaların yapıldığg (Develi, 2020; Doğanay Bilgi, 2009; Duman, 2006; Gökbulut, vd., 2020; Güldenoğlu \& Kargın, 2012; Güler, 2008; Güzel, 1998; İlter, 2018; İşcan, 2016; İnceCora, 2007; Kalkan, 2009; Kudret vd., 2016; Sanır vd., 2020; Tahiroğlu, 2014; Özak, 2017) görülmektedir. Zihinsel yetersizliği olan öğrencilere okuduğunu anlama becerilerini etkili bir 
şekilde kazandırmak ve öğrencilerin çok yönlü gelişimini desteklemek amacıyla uygulanabileceği düşünülen yöntemlerden biri de yaratıcı dramadır. Adıgüzel'e göre (2010):

Yaratıcı drama; bir grupla ve grup üyelerinin yaşantılarından yola çıkarak, bir amacın, düşüncenin, doğaçlama, rol oynama (rol alma) vd. tekniklerle canlandırılmasıdır. $\mathrm{Bu}$ canlandırma süreçleri deneyimli bir lider/eğitmen eşliğinde yürütülürken, kendiliğindenliğe (spontaniteye), şimdi ve burada ilkesine, -mış gibi yapmaya dayalıdır ve yaratıcı drama, oyunun genel özelliklerinden doğrudan yararlanmaktadır (s. 56).

Yaratıcı drama bir disiplin olması ve diğer disiplinlerde bir öğretim yöntemi olarak kullanılması ile iki temel boyutta kullanılabilmektedir (Adıgüzel, 2020).

Podlozny (2000), son 35 yılda, yaklaşık 200 deneysel çalışmanın yapıldığını, bu çalışmaların yaratıcı drama öğretimi ile akademik becerinin değişik biçimleri arasındaki ilişkiyi değerlendirdiğini belirtmektedir. Bu çalışmaların \%40 'ından fazlası drama öğretimi ile okuma, sözlü dilin gelişmesi ve yazmayı içeren sözel alanlardaki akademik başarı arasındaki ilişkiyi incelemektedir.

McMaster (1998)'e göre yaratıcı drama, okuma yazma gelişimi için etkili bir yöntemdir. Yaratıcı drama; ortak çalışma yapmak için öğrencilerde motivasyon yaratmakta ve okuma öğretiminde öğrencilerin isteklerine uygun olanakları oluşturmaktadır. Yaratıcı drama sürecinde gerçekleştirilen dramatik etkinlikler öğrencilerin sesli okuma pratiği yapabilecekleri ve okuma akıcılığını geliştirebilecekleri bir ortam sağlamaktadır. Bu süreç, öğrencilerin, yaratıcı drama içeriğinde sunulan yeni sözcükleri görsel, işitsel, kinestetik olarak kavrayabilmeleri için de olanak sağlamaktadır.

Booth (1985)'a göre, öğrenciler yaratıcı drama sürecinde metinleri okudukları zaman sözcüklerin anlamlarını anlamakta, okudukları deneyimi kendi özel bağlamlarına çevirmekte ve yazarın değerlerinden gelen herşeye ilişkin hisleri, tutumları ve fikirleri ile kendi yaşamları arasında ilişki kurmaktadırlar. $\mathrm{Bu}$ yeni anlamlar dünyasının içerisinde öğrenciler, dış 
müdahalelerden bağımsız olarak, kendi verdikleri kararları uygulamakta, kişisel olarak tepki ve yanıt vermektedirler. Yaratıcı drama deneyiminin etkileşimli, katılımcı modeli, öğrencilerin farklı bir yolda gelişmesine yardım etmekte, yeni, grupça anlamaya doğru onları taşımaktadır. Yaratıcı drama süreci, kendi başına öğrencilerin öğrenmelerinin gerçekleşmesine yardımcı olmak için güçlü bir ortamdır. Rose ve diğerleri’ne (2000) göre yaratıcı drama stratejileri, öğrencilerin dürüst ve cesur bir şekilde, bir hikâyenin temel öyküsünü takip etmelerine, öğrencilerin karakterin durumu ile kendilerini özdeşleştirmelerine ve her durumu benzer sürpriz duygusu ile yaşayarak ortaya koymalarını sağlamaktadır (Akt; Kelin, 2007).

Yaratıcı drama, ortak çalışma yapmak icin öğrencilerde motivasyon yaratmakta ve okuma öğretiminde öğrencilerin isteklerine uygun olanak sağlamaktadır. Oyun için seçilen bir metnin tekrarlamalı okunması yoluyla, öğrencilerin okuma akıcılıklarını geliştirmelerine de firsat vermektedir. Yaratıcı drama, okunan metin üzerinde durulan noktayı anlamalarını ve yorumlamalarını gerektirdiğinden, bu yolla öğrenciler, daha derinlemesine bir anlama becerisi de geliştirebilmektedirler (McMaster, 1998).

Ülkemizde yaratıcı drama yönteminin özel eğitim alanının farklı beceri ve konularında kullanımı ile ilgili araştırmalar (Akfırat \& Önalan, 2004; Arbay \& Akfırat 2012; Avcıoğlu, 2012; Bayhan, 1995; Bayhan \& Yükselen 2007; Kaya \& Eratay, 2009; Kangal, 2010; Kangal \& Ar1, 2013; Dibek, 2003; İpek, 1998; Kaya, 2011; İpek, 1998; Ovayurt \& Akfirat, 2016; Ömeroğlu, 1992; Tüfekçi, 2007) bulunmakla birlikte, okuma becerisi ile ilgili olarak yapılan çalışmalar sınırlı sayıdadır (Çolak, 2019). Özel eğitim alanının farklı yetersizlik gruplarıyla, okuma ve anlama becerisinin çalışıldığı, yurt dışında gerçekleştirilen araştırmalar da (Babudoh 2014; Önemli, Totan \& Abbasov, 2015; Park, 1998) mevcuttur. Ancak hem ulusal hem de uluslararası alanyazında zihinsel yetersizliği olan öğrencilerde yaratıcı drama yöntemiyle okuduğunu anlama becerileri öğretiminin etkililiğinin incelendiği herhangi bir çalışmaya rastlanmamıştır. Bu durum yaratıcı drama yönteminin zihinsel yetersizliği olan öğrencilerin 
okuduğunu anlama becerileri üzerindeki etkisini araştırmak ve bu alana katkı oluşturabilmek açısından önem teşkil etmektedir. Bu araştırmanın amacı, yaratıcı drama programının hafif düzeyde zihinsel yetersizliği olan öğrencilerin okuduğunu anlama becerilerinin geliştirilmesi açısından etkili olup olmadığını belirlemektir. Bu amaç kapsamında aşağıdaki sorulara yanıt aranmıştır.

1) Yaratıcı drama eğitim programına devam eden deney grubu ile geleneksel yöntemde eğitim alan kontrol grubu öğrencilerinin okuduğu metinlerle ilgili olarak aldıkları ön test puanları arasında anlamlı bir fark var mıdır?

2) Yaratıcı drama eğitim programına devam eden deney grubu ile geleneksel yöntemde eğitim alan kontrol grubu öğrencilerinin okuduğu metinlerle ilgili olarak aldıkları son test puanları arasında anlamlı bir fark var mıdır?

3) Yaratıcı drama programına dâhil olan deney grubu ile dâhil olmayan kontrol grubu öğrencilerinin aldıkları izleme testi puanları arasında anlamlı bir fark var midır?

4) Yaratıcı drama programına dâhil olan deney grubundaki öğrencilerin okuduğu metinlerle ilgili olarak aldıkları ön test, son test ve izleme testleri puanlarının arasında anlamlı bir fark var mıdır?

5) Kontrol grubundaki öğrencilerin okuduğu metinlerle ilgili olarak aldıkları ön test, son test ve izleme testleri puanlarının arasında anlamlı bir fark var mıdır?

\section{YÖNTEM}

\subsection{Araştırma Modeli}

Araştırmada eşleştirilmiş ön test- son test kontrol gruplu desen (ÖSKD) kullanılmıştır. Bu desende "bağımlı değişkenle ilişkili olduğu düşünülen değişkenlere ait değerleri aynı olan denek çiftleri oluşturulur. Çiftlerden biri birinci gruba, diğeri ikinci gruba atanır” (Büyüköztürk, 2001). Desende eşleştirilmiş atama ile oluşturulmuş deney ve kontrol grubu bulunmaktadır. 
Müdahaleye başlamadan önce deney ve kontrol gruplarının ölçülmek istenen özelliklerine ilişkin değerlendirmeler alınır ve daha sonra müdahale uygulanır. Müdahale tamamlandıktan sonra deney grubunda oluşan değişiklikler kontrol grubu ile karşılaştırılır. Bu desende, deney grubundaki değişimin kontrol grubundaki değişime göre ne kadar farklı olduğu ortaya çıkarılır. Böylece müdahalenin etkileri belirlenir. Deney öncesi ve sonrasında birer ölçüm yapılan desenin simgesel görünümü Tablo1'de verilmiştir (Büyüköztürk, vd., 2014).

\section{Tablo 1}

Eşleştirmeli Grup Ön Test-Son Test Desenin Simgesel Görünümü

\begin{tabular}{ccccc}
\hline Grup & Ön Test & İşlem & Son Test \\
& $\mathrm{D}$ & 01 & $\mathrm{X}$ & 03 \\
\hline $\mathrm{K}$ & $\mathrm{O} 2$ & & 04
\end{tabular}

\subsection{Bağımlı ve Bağımsız Değişken}

$\mathrm{Bu}$ araştırmanın bağımlı değişkeni okuduğunu anlama becerisidir. Bu çalışmada, okuduğunu anlama becerisini geliştirme tekniklerinden olan okuduğu metin ile ilgili sorulara cevap verme becerisinin öğretimi yapılmıştır. Okuduğunu anlama becerisi kapsamında çalış1lan hedef davranışlar:

Metindeki bilmediği sözcüklerin anlamını metnin içeriğinden çıkarma, metindeki olay kahramanlarının kimler olduğunu söyleme, metindeki olay kahramanlarının kimler olduğunu yazma, metindeki olayın geçtiği yeri söyleme, metindeki olayın geçtiği yeri yazma, metindeki olayın zamanını söyleme, metindeki olayın zamanını yazma, metindeki başlatıcı olayı söyleme, metindeki başlatıcı olayı yazma, metindeki kişi veya kişilerin başlatıcı olay karşısında verdiği içsel tepkiyi söyleme, metindeki kişi veya kişilerin başlatıcı olay karşısında verdiği içsel tepkiyi yazma, metinde geçen olaya ilişkin girişimi söyleme, metinde geçen olaya ilişkin girişimi yazma, metinde geçen olaya ilişkin girişimin sonucunu söyleme, metinde geçen olaya ilişkin girişimin sonucunu yazmadır. 
$\mathrm{Bu}$ araştırmanın bağımsız değişkeni ise; hafif düzeyde zihinsel yetersizliği olan öğrencilerin, metin ile ilgili sorulara cevap verme becerilerini öğrenme düzeylerini etkileyecek olan, yaratıcı drama yöntemi kullanılarak oluşturulan Okuduğunu Anlama Öğretim Programı’dır (OAÖP).

\section{3. Çalışma Grubu}

Araştırma Ankara'da MEB'e bağlı özel bir eğitim ve rehabilitasyon merkezinde ve bu merkezde eğitim gören öğrenciler arasından seçilerek gerçekleştirilmiştir.

Öğrencilerde aranan önkoşullar: (1) Rehberlik ve Araştırma Merkezleri'nde (RAM'da) yapılan değerlendirmeler sonucunda "Eğitilebilir Zihinsel Yetersizlik" olarak tanılanma ve bireyin destek eğitim almasının uygun görülmesi, (2) İlgili hastanelerin sağlık raporlarına göre “Hafif Düzeyde Zihinsel Yetersizlik” tanısı alma, (3) İlkokul 2. Sınıflardaki bağımsız okuma ve yazma becerisine sahip olma ve okuma becerilerinden dinleme, sesli ve sessiz okuma becerilerinde yeterlilik gösterme, (4) Sesli Okuma Testi’nde ikinci sınıf öğrencilerinin öğretimsel düzeyine (sorulara \%70-89 doğru yanıt verme) sahip olma olarak belirlenmiştir

$\mathrm{Bu}$ ön koşul becerilere sahip olan öğrencilerin belirlenmesi için araştırmacı tarafından öğrencilerin Özel Eğitim ve Rehabilitasyon Merkezi’ndeki dosyaları incelenmiş ve ön koşul özelliklerini gösteren 19 öğrenci tespit edilmiştir. Araştırmacı öğrencilerin ders öğretmenleriyle, öğrencilerin araştırmaya uygunluğu hakkında bire bir görüşme yapmıştır. Bu görüşmelerden sonra araştırmacı tarafından 19 öğrenciyle bir ön değerlendirme oturumu gerçekleştirilmiştir. Bu ön değerlendirme oturumlarında Şenel (1998) tarafından geliştirilen Sesli Okuma Testi'nden ve Cora-İnce (2007) tarafından hazırlanan ve (1) Dinleme Becerileri, (2) Sesli Okuma Becerileri, (3) Sessiz Okuma Becerileri, (4) Okuduğu Metinle İlgili Sorulara Cevap Verme Becerisi, (5) Okuduğu Metnin Ana Fikrini Bulma Becerisi, (6) Okuduğu Metni Özetleme Becerisi olmak üzere altı bölümden oluşan Okuduğunu Anlama Becerileri Kontrol Listesi (OABKL)'nden yararlanılmıştır. 
Araştırmac1, Sesli Okuma Testi’ni, her öğrenciye, önceden belirlenen Bireysel Eğitim Sınıfında, 40 dk. süre ile bireysel olarak uygulamıştır. Sesli Okuma Testi'nin uygulanması sırasında tüm oturumlar, hata analizi yapılabilmesi ve okuduğunu anlama becerisinin değerlendirilebilmesi için kameraya kaydedilmiştir. Her öğrenciye kamera kaydı yapılacağı, uygulama yapılmadan önce belirtilmiştir. Kamera kaydından rahatsız olduğunu belirten hiçbir öğrenci olmamıştır. Testin sonucunda araştırma için ön koşul özelliklerini gösteren öğrenci sayısı 12 olarak belirlenmiştir.

Belirlenen ön koşul özelliklerine sahip olan öğrencilerin okuma becerileri düzeylerinin belirlenmesinde yararlanılan bir diğer araç olan OABKL, 12 öğrenci için öğrencilerin bireysel derslerine giren üç öğretmen tarafından puanlanmıştır. Puanlama "her zaman yapar-3, ara sıra yapar-2, hiçbir zaman yapmaz-1" şseklinde yapılmıştır. Araştırmacı da belirlenen bu 12 öğrencinin Türkçe derslerine gözlemci olarak katılmış, gözlemleri sonucunda OABKL'ni aynı şekilde puanlamıştır. Tüm bu çalışmaların sonucunda OABKL'nin puanlama işlemi 4 alan uzmanı tarafından yapılmıştır. Bu süreçte uzmanların puanlamaları arasındaki tutarlılığın istatistiksel tekniklerle belirlenmesi gerekmektedir (Kutlu, Doğan \& Karakaya, 2010). İkiden fazla puanlayıcı arasındaki uyum düzeyine bakılması gerektiği durumlarda sıralı ölçek düzeyindeki değişkenler için Krippendorff Alfa istatistiği kullanılabilir. Her bir öğrenci için hesaplanan puanlayıcılar arası uyuşum yüzdelerinin 0.75 ile 0.96 arasında değiştiği bulunmuştur. Bu değerler puanlayıcılar arası uyum düzeyinin genellikle yüksek olduğunu ve bir öğrencide ise uyuşum gücünün orta olduğunu göstermektedir (Hayes \& Krippendorff, 2007; Krippendorff, 1995, 2004).

Yapılan değerlendirmeler sonucunda, belirtilen ön koşulları sağlayan 8 öğrenci çalışma grubuna seçilmiş olup, uygulama bu öğrencilerle yapılmıştır. Deney ve kontrol grupları oluşturulurken gruplar, eşleştirilmiş atama yoluyla belirlenmiştir. Bu 8 öğrencinin içerisinde, ön koşul becerilerine sahip olan 4 denek çifti bulunduğundan; öğrenciler 2'li eşleştirilmiş ve 
2’liler arasından kura çekilerek deney ve kontrol grubu oluşturulmuştur. Kura sonucunda bu öğrencilerden 4 öğrenci ( $2 \mathrm{~K} 1 \mathrm{z}, 2$ Erkek) deney, 4 öğrenci (4 Erkek) kontrol grubunu oluşturmuştur. Tablo 2'de deney ve kontrol grubundaki öğrencilerin cinsiyet, yaş, ilgili hastanelerden aldıkları tanılarına ve öğrenim gördükleri sınıf düzeylerine yer verilmiştir.

\section{Tablo 2}

Çalışma Grubunda Yer Alan Öğrencilerin Özellikleri

\begin{tabular}{llllll}
\hline \multicolumn{6}{c}{ Öğrencilere İlişkin Değişkenler } \\
\hline & No & Yaş & Cinsiyet & Tanı & Sinıf \\
\hline Deney & 1 & 12 & E & Hafif Düzeyde Zihinsel Yetersizlik & 5. Sinıf \\
Grubu & 2 & 16 & E & Hafif Düzeyde Zihinsel Yetersizlik & 9. Sinıf \\
& 3 & 17 & K & Hafif Düzeyde Zihinsel Yetersizlik & 9. Sinıf \\
& 4 & 20 & K & Hafif Düzeyde Zihinsel Yetersizlik & Mezun \\
\hline \multirow{3}{*}{ Kontrol } & 1 & 10 & E & Hafif Düzeyde Zihinsel Yetersizlik & 3. Sinıf \\
& 2 & 16 & E & Hafif Düzeyde Zihinsel Yetersizlik & 9. Sinıf \\
& 3 & 18 & E & Hafif Düzeyde Zihinsel Yetersizlik & 10. Sinıf \\
& 4 & 21 & E & Hafif Düzeyde Zihinsel Yetersizlik & Mezun \\
\hline
\end{tabular}

\subsection{Etik}

Araştırmacı tarafından, araştırmaya katılan sekiz öğrencinin ailelerine araştırma hakkında bilgi verilmiş ve “Anne - Baba İzin Formu” imzalatılmıştır. Bu formda araştırmacının öğrencilerin okuduğunu anlama becerilerini geliştirmek için öğrencilerle belirlenen süre kadar periyodik çalışmalar yürüteceği, araştırma boyunca gizlilikten hiç vazgeçilmeyeceği, çalışmaya katılan öğrencilerin isimlerinin raporda yer almayacağı, öğrenciye yönelik davranışsal ya da fiziki bir risk taşımadığı, görüntülerin ise araştırma amacıyla kullanılacağı ve sadece araştırmacıların görebileceği belirtilmiştir. Ayrıca çalışma öncesi ve çalışma süreci boyunca araştırmacının her türlü soruya yanıt vereceği açıklanmıştır. Aileler araştırmacı tarafindan açıklanan tüm süreci Anne - Baba İzin Formu'nu imzalayarak, onaylamışlardır. 


\subsection{Veri Toplama Araçları}

\subsubsection{Okuma Parçaları (Metinler)}

$\mathrm{Bu}$ araştırmada, öğrencilerin okuduğu metinle ilgili sorulara cevap verme becerilerini geliştirmek için okuma parçalarından yararlanılmıştır. Araştırmanın pilot uygulama, ön test ve son test, uygulama ve izleme aşamalarında kullanılacak olan bu okuma metinlerini Cora-İnce (2007) geliştirmiştir.

Okuma parçaları, okuduğu metin ile ilgili sorulara cevap verme becerisini, okuduğu metnin ana fikrini bulma becerisini ve okuduğu metni özetleme becerisini ölçmek amaciyla her beceri için 15 hikâye olmak üzere toplam 45 hikâyeyi içermektedir. Cora İnce (2007) hazırlamış olduğu hikâyeler, dil bilgisi yönünden, içerik yönünden, biçim yönünden, sorular yönünden, ana fikir ve yardımcı fikir yönünden ve özetleme yönünden yargıcılar tarafından değerlendirilmesi amacıyla Abant İzzet Baysal Üniversitesi Eğitim Fakültesi Türkçe Eğitimi Bölümü öğretim elemanlarının değerlendirilmesine sunulmuştur. $\mathrm{Bu}$ değerlendirme sonucunda, okuma metinleri yeniden düzenlenmiştir. Okuma metinleri dört bölümden oluşmaktadır. Bunlar dekor, giriş ve sonuç bölümleridir. Metin uzunlukları ortalama olarak 100 sözcük ile anlatım ise 3. şahısla sınırlandırılmıştır. Mecazlı söyleyişlere yer verilmemiştir. Okuma metinleri yazılmadan önce metinlerdeki içeriğin belirlenmesi amacıyla ilkokul 2. ve 3 . sınıf hayat bilgisi dersinin konuları incelenmiş ve bu konular çerçevesinde ana fikirler oluşturulmuştur (s.65).

Bu araştırmada, deney ve kontrol gruplarında, yukarıda bahsedilen 45 metinden 2'si ön test ve son testte, 8'i uygulama aşamasında; 2'si ise izleme oturumunda kullanılmak üzere toplam 12 metin seçilmiştir. Araştırmanın pilot uygulaması için; "Caddeye Kaçan Top”, ön test ve son test uygulamaları için; "Boncuğun Temizliği ve Kırılan Ağaç Dalları”, araştırmanın uygulama aşaması için; “Bozulan Telefon”, "Dağınık Oda”, “Kaldırımda Oyun”, “Penceredeki 
Kuş", "Yalanın Sonu”, "Yalnızlığın Sonu”, “Zeynep'in Rüyası" ve "Caddeye Kaçan Top”, araştırmanın izleme bölümü için de "Görünmez Kaza" ve "Oyun Kartları" adlı metinler kullanılmıştır.

Seçilen 12 metnin; metin ile ilgili sorulara cevap verme becerisine yönelik olarak, Cora İnce (2007) tarafından geliştirilmiş ayrı ayrı 10 sorusu bulunmaktadır. Deney grubu ile yaratıcı drama yöntemi, kontrol grubu ile geleneksel yöntem kullanılarak bu metinler okunduktan sonra her bir öğrenciden metinlere ait soruları yazılı olarak yanıtlaması istenmiştir.

Öğrencilerin verdikleri cevapların eşit şekilde puanlanabilmesi için dereceli puanlama anahtarına ihtiyaç duyulmuştur. Özel eğitim alanında çalışan ve aynı zamanda yaratıcı drama eğitimi almış 4 alan uzmanı ön test, son test ve izleme metinlerini inceleyerek dereceli puanlama anahtarını oluşturmuşlardır. Sorulara verilen cevaplarda öğrencilerin metinleri anlama düzeyi dikkate alınmıştır. Sorular likert tarzda değerlendirilmiş olup, sorulan verilen cevaplar en yüksek puan 5 ve en düşük puan 1 biçiminde değerlendirilmiştir. Araştırmacı bu 4 farklı dereceli puanlama anahtarını değerlendirerek; ön test ve son test ve izleme testlerinin dereceli puanlama anahtarlarına son şekillerini vermiştir. Puan ağırlıkları Tablo 3’te gösterilmiştir. 


\section{Tablo 3}

Dereceli Puanlama Anahtarına Verilen Puan Aralıkları

\begin{tabular}{lc}
\hline \multicolumn{1}{c}{ Seçenek } & Verilen Puan \\
\hline Hiç anlamad 1 & 1 \\
Anlamad 1 & 2 \\
Kısmen anlad 1 & 3 \\
Anlad 1 & 4 \\
Çok iyi anladı & 5 \\
\hline
\end{tabular}

\subsubsection{Veri Toplama Formlart}

Araştırmanın ön test, son test ve izleme oturumlarından sonra öğrencilerin okuduğu metinle ilgili sorulara cevap verme becerilerini ölçmek için Okuduğu Metin İle İlgili Sorulara Cevap Verme Becerisine Yönelik Veri Kayıt Formları kullanılmıştır.

Öğrencilerden ön test, son test ve izleme metinlerini okuduktan sonra okudukları metnin sorularını sözlü ve yazılı olarak cevaplamaları istenmiş ve bu sürecin güvenirlik analizinin yapılabilmesi için kamera kaydı alınmıştır. Öğrencilerin sorulara verdiği cevapların, Okuduğu Metin İle İlgili Sorulara Cevap Verme Becerisine Yönelik Veri Kayıt Formu'na göre eşit puanlanabilmesi için; özel eğitim alanında çalışan ve yaratıcı drama eğitimi almış 3 alan uzmanı tarafindan her bir öğrenciye ait 40'ar dakikalık videolar izlenmiştir. Her öğrencinin sorulara verdiği cevaplar, alan uzmanlarınca hazırlanan dereceli puanlama anahtarına göre puanlanmış ve Okuduğu Metin İle İlgili Sorulara Cevap Verme Becerisine Yönelik Veri Kayıt Formu'na işaretlenmiştir.

Buna göre, ön test uygulamasından sonra Okuduğu Metin İle İlgili Sorulara Cevap Verme Becerisine Yönelik Veri Kayıt Formu'na puanlamalar "beceri var 1 - beceri yok 0" şeklinde, son test uygulamasından sonra Okuduğu Metin İle İlgili Sorulara Cevap Verme Becerisine Yönelik Veri Kayıt Formu'na puanlamalar “ beceriyi yaptı 1- beceriyi yapamadı 0" şeklinde ve izleme testi uygulamasında Okuduğu Metin İle İlgili Sorulara Cevap Verme 
Becerisine Yönelik Veri Kayıt Formu'na puanlamalar; “ beceri devam ediyor 1- beceri devam etmiyor 0" şeklinde yapılmıştır.

\subsection{Uygulama Süreci}

Araştırmada, zihinsel yetersizliği olan çocukların okuduğunu anlama becerisine yönelik olarak yaratıcı drama yoluyla Okuduğunu Anlama Becerileri Öğretim Programı (OABÖP) hazırlanmıştır. OABÖP’te yer alan yaratıcı drama oturumları için toplam 8 okuma metni ve her bir metnin on soruluk anlama soruları kullanılmıştır. Hazırlanan yaratıcı drama oturumları okuduğunu anlama becerisi öğretim hedeflerinin yanında, işlenen metnin kazanımlarını da içerecek şekilde planlanmıştır. $\mathrm{Bu}$ nedenle toplam 8 ayrı yaratıcı drama oturum planı hazırlanmıştır.

Adıgüzel'e göre yaratıcı drama hazırlık - 1sınma, canlandırma ve değerlendirme olmak üzere üç aşamadan oluşmaktadır (Adıgüzel, 2006, Adıgüzel, 2013). Araştırmacı tarafından bu bilgiler doğrultusunda hazırlanan OABÖP, hedef-davranış, içerik, öğrenme- öğretme süreci ve değerlendirme öğelerinin uygunluğu açısından değerlendirilmek amacıyla Ankara Üniversitesi Yaratıcı Drama Programı'nda görev alan bir öğretim üyesinin ve özel eğitimde yaratıcı drama çalışmaları yapan başka bir öğretim üyesinin görüşlerine sunulmuştur. Bu değerlendirmelerin sonucunda hazırlanan program araştırmacı tarafından yeniden düzenlenmiş ve programa son hali verilmiştir. Hazırlanan “Bir Uygulama Planı Örneğì” Ek 1'de sunulmuştur.

\subsection{1. Ön test - Son test Oturumlart}

Araştırmada, deney ve kontrol gruplarına "Kırılan Ağaç Dalları" ve "Boncuğun Temizliği” metinleri ön test ve son test olarak uygulanmıştır.

Bu öğrencilere, ilk önce Boncuğun Temizliği adlı metin okutulmuştur. Metni okumaya başlamadan önce, öğrenciye yapılacak uygulama hakkında kısa bir bilgi verilmiştir. Öğrenciden metni sesli olarak okuması istenmiştir. Araştırmacı öğrencinin hatalı ya da zorlanarak okuduğu yerleri düzeltmiştir. Öğrenci metnin hepsini okuduktan sonra, metin öğrencinin önünden 
alınmış ve metinle ilgili olan 10 soru, uygulamacı tarafından tek tek sözlü olarak sorulmuştur. Öğrenci kendisine sorulan soruları dikkatlice dinleyip, sözlü ve yazılı olarak cevaplandırmıştır. Uygulama sonunda öğrencinin katılımı için teşekkür edilip, pekiştirilerek uygulama bitirilmiştir. Araştırmaya katılan tüm öğrenciler için aynı şekilde uygulama yapılmıştır. Her bir uygulama 40'ar dakika sürmüş ve güvenirlik analizleri yapılabilmesi için kameraya kaydedilmiştir. Aynı işlem Kırılan Ağaç Dalları adlı metin için de her bir öğrenci ile tekrarlanmıştır.

Ardından araştırmacı ve iki alan uzmanı tarafından bu videoların hepsi izlenmiştir. Bu aşamada öğrencilerin metni okuduktan sonra yazılı ve sözlü olarak verdiği cevaplar, oluşturulan dereceli puanlama anahtarına göre puanlanmıştır.

\subsubsection{Pilot Uygulama}

Araştırmada, uygulamaya başlamadan önce pilot uygulama yapılmıştır. Pilot uygulama araştırmaya katılan öğrencilere benzer özelikte 4 zihinsel yetersizliği olan öğrenciye uygulanmıştır. Pilot uygulama, çalışmaların yapılacağı drama odasında gerçekleştirilmiş ve 90 dakika sürmüştür.

Pilot uygulama sırasında öğrenciler için Cora İnce (2007) tarafından geliştirilen metinlerden biri olan Caddeye Kaçan Top metni kullanılmıştır. Oturum sonrasında her bir öğrenciye metinle ilgili 10 sorunun bulunduğu kağıtlar dağıtılmış, bu kağıtları yazılı olarak doldurmaları istenmiştir. Ardından araştırmacı tarafından Okuduğu Metin İle İlgili Sorulara Cevap Verme Becerisine Yönelik Veri Kayıt Formu oluşturulan cevap anahtarına göre değerlendirilmiştir. Yapılan pilot uygulama video kamera ile kaydedilmiştir. Uygulama sonunda kayıtlar izlenmiştir. Araştırmanın sağlıklı bir şekilde yapılabilmesi için gerekli görülen düzenlemeler yapılıp, hazırlanan yaratıcı drama oturumlarına ve yaratıcı drama salonuna son hali verilmiştir. 


\subsection{3. Öğretim Oturumları}

Öğretim programının uygulama çalışmaları araştırmacı tarafından, Özel Eğitim ve Rehabilitasyon Merkezi'nde yer alan drama salonunda yapılmıştır. Bu drama salonunda; gerektiğinde kullanılabilecek küçük masalar, sandalyeler, tahta, CD çalar, minderler ve materyal dolabı yer almaktadır. Drama salonunda öğrencilerin dikkatini dağıtacak görsel uyaranlar ortadan kaldırılmıştır. Öğrencilerin performans düzeyleri bireysel sınıflarda belirlendikten sonra, pilot, uygulama ve izleme oturumları bu drama salonunda gerçekleşmiştir. Yapılan yaratıcı drama oturumları güvenirlik analizleri yapılabilmesi için sabit bir kamera ile kayıt edilmiştir. Kamera çalışmaya başlamadan önce drama odasına katılımcıların dikkatini dağıtmayacağı bir yere monte edilmiştir.

Araştırmaya katılan deney grubuyla, haftada bir gün, 90 dakika süren ve 8 oturumdan oluşan okuduğunu anlama becerileri öğretimi gerçekleştirilmiştir. Uygulamaya başlarken araştırmacı (lider) kendini tanıtmış, yaratıcı drama çalışması hakkında öğrencilere kısaca açıklamada bulunulmuştur. $\mathrm{Bu}$ süreçte araştırmacının (liderin) yönergelerinin çok önemli olduğu açıklanmış ve etkinlik esnasında bu yönergeleri yerine getirmelerinin önemi anlatılmıştır. Öğrencilere yaratıcı drama kuralları anlatılmış, anlatılanların genel olarak anlaşılıp anlaşılmadığını belirlemek için de gruba sorular sorulmuştur.

Yaratıcı drama oturumlarının "Hazırlık - Isınma” bölümlerinde grup dinamiğini oluşturmak için oyunlar oynanmıştır. Oyunlar oynandıktan sonra katılımcılardan ara değerlendirmeler alınmış, oynanan oyunlar arasında bağlantılar kurmaları hedeflenmiştir. Ara değerlendirmeler öğrencilerin süreçten kopmamalarını da sağlamış, okunan metinle de ilişki kurmalarını kolaylaştırmıştır. (Oyunlar seçilirken bireysel olarak okuyacakları metinle de bağlantılı olmasına dikkat edilmiştir. Örneğin; "Kaldırımda Oyun" adlı metinde, metnin kahramanı Sevgi, caddenin kenarındaki kaldırımda yerden yüksek oyunu oynuyordur. O metne ait yaratıcı drama oturumunun Hazırlık Isınma aşamasında Yerden Yüksek oyunu oynanır. Ara 
değerlendirme bölümünde de öğrencilere "Bu oyunu nerelerde oynayabiliriz?” sorusu sorulur. Bu nedenle oyunlar hem metnin içerdiği kazanımla hem de konusuyla bağlantılı olacak şekilde planlanmıştır.)

Yaratıcı drama oturumunun "Canlandırma" bölümünde; metin içerisinde geçen konunun öğrenciler (katılımcılar) tarafından okunup, doğaçlama, rol oynama gibi tekniklerle canlandırıldığı, grup ya da bireysel canlandırmalar üzerine grupça konuşup, öğrencilerin kendi düşüncelerini söylediği etkinlikler yapılmıştır.

Yaratıcı drama oturumlarının Canlandırma bölümlerinde öğrencilerden sabit ikili gruplar oluşturulmuş, metinle ilgili çalışmaları bu değişmeyen ikili gruplar sürdürmüştür. Yaratıcı drama süreci içerisinde nitelikli eşli okuma çalışması yapabilmeleri, birbirlerine sesli ve sessiz olarak okumaları, bilmedikleri kelimeleri metinde seçip, sözlükten bulup bu kelimeleri cümle içerisinde kullanmaları için ikili gruplardaki kişiler değiştirilmemiştir. Kişilerin değişmemesindeki bir diğer amaç ise; öğrencilerin dikkatli bir şekilde metinle ilgili çalışma yürütebilmeleri, odaklanabilmeleridir.

Öğrenciler metindeki konuları grup olarak canlandırmışlardır. Bu canlandırmalarda öğrencilerden metindeki kişilerin, metinde geçen zamanın, mekânın, olayların açık olarak sunulduğu canlandırmalar hazırlamaları istenmiştir. Metne dayalı olarak yapılan canlandırmalardan sonra ara değerlendirmeler alınarak, canlandırmalar hakkında "kimlerin olduğu, hangi zamanda ve nerede geçtiği, olayın ne olduğu ve nasıl çözüldüğü” grup olarak tartışılmıştır. Ara değerlendirmeler aynı zamanda katılımcılar metinden bağımsız canlandırmalar yaptıklarında katılımcıların odaktan kaymamalarını sağlamıştır. Araştırmacı (lider) tüm süreç boyunca, öğrencileri gözlemlemiş, doğaçlama ve rol oyunlarında, grup etkinliklerinde öğrencilerin etkinlikleri nasıl yapabilecekleri ile ilgili gerekli açıklamalar ve sözel yönlendirmeler yapmıştır. 
Yaratıcı drama oturumunun "Değerlendirme - Tartışma" bölümünde; öğrencilerle metindeki bilgi ve eğitsel kazanım üzerine konuşulmuş ve tartışılmıştır. Öğrencilerin etkinlikte yaşanılanları özetlemeleri sağlanmış, fark ettikleri kazanımları, yaşantılarında nerelerde, nasıl kullanacakları hakkında konuşmalar yapılmıştır. Yaratıcı drama oturumlarının bu bölümlerinde, öğrenciler hem deneyimledikleri süreçleri hem de okudukları metinle ilgili olarak değerlendirmeleri poster hazırlama, afiş tasarlama, resim yapma gibi kendi yaptıkları etkinliklerle değerlendirmişlerdir. Hazırladıkları değerlendirmeleri tüm gruba sesli olarak anlatmışlardır. Araştırmacı, öğrencilerin uygulama anındaki etkinlikte arkadaşları ile ne kadar uyumlu oldukları hakkında öğrencilere bilgiler vermiş̧tir. Öğrencilere her oturum sonunda, süreçte aldıkları görev ve sorumlulukları uyum içerisinde yerine getirdiklerini belirtilerek, pekiştirmiştir. Bu bilgiler 1şı ğında:

OABÖP'nin birinci oturumunda Dağınık Oda metni işlenmiştir. Hazırlık-Isınma aşamasında Eşya Sepeti ve Kuluçkadaki Tavuk oyunları oynanmıştır. Oyunlardan sonra Ara Değerlendirme alınarak, öğrencilere iki oyunun kuralları arasında benzerlik hakkında sorular sorulmuştur. Canlandırma aşamasında, metin olay sırasına göre canlandırılmıştır. Değerlendirme aşamasında ise öğrencilerin oynanan oyunlarla metin arasında bir benzerlik olup olmadığı hakkında konuşulmuştur. Ardından öğrencilerin sırayla "Ben bugün öğrendim.” cümlesini tamamlamaları istenmiştir.

İkinci oturumunda; Caddeye Kaçan Top adlı metin işlenmiştir. Sürecin başında gazete çalışanları olarak görev almışlar ve bundan sonraki tüm sürece bu görevle devam etmişlerdir. Canlandırma aşamasında, yine gazete çalışanları görevleriyle metni canlandırmışlar, değerlendirme aşamasında ise oturum boyunca yaptıkları tüm süreci konuşup ve metinle ilişkisini kuran “Ben bugün .... öğrendim.” cümlesini tamamlamışlardır.

Üçüncü oturumunda; Bozulan Telefon adlı metin işlenmiştir. Hazırlık-Isınma aşamasında ev telefonu, cep telefonu ve ankesörlü telefonla ilgili etkinlikler yapılmıştır. 
Canlandırma aşamasında, metin olay sırasına göre canlandırılmıştır. Değerlendirme aşamasında metinle ilgili sorular sorularak öğrenciler düşüncelerini paylaşmışlardır.

Dördüncü oturumunda; Kaldırımda Oyun metni işlenmiştir. Hazırlık-Isınma aşamasında Yerden Yüksek ve Dokunmatik Robot oyunları oynanmıştır. Oyunlardan sonra Ara Değerlendirme alınarak, öğrencilere iki oyunun kuralları arasında benzerlik hakkında sorular sorulmuştur. Canlandırma aşamasında, metin olay sırasına göre canlandırılmıştır. Değerlendirme aşamasında ise öğrenciler çocukların nerede oyun oynamaları gerektiğini anlatan bir afiş hazırlamışlardır.

Beşinci oturumunda; Zeynep'in Rüyası adlı metin işlenmiştir. Hazırlık-Isınma aşamasında Diş Sepeti ve Mikroplar oyunu oynanır. Oyunlardan sonra Ara Değerlendirme alınarak, öğrencilere iki oyun arasında benzerlik hakkında sorular sorulmuştur. Canlandırma aşamasında, metin olay sırasına göre canlandırılmıştır. Değerlendirme aşamasında ise "Ben bugün ..... öğrendim.” cümlesini tamamlamaları istenmiştir.

Altıncı oturumunda; Penceredeki Kuş metni işlenmiştir. Hazırlık-Isınma aşamasında Kuş Kafeste oyunu oynanmıştır. Canlandırma aşamasında, Hayvanları Koruma Derneği çalışanları olarak role girilmiş ve metin olay sırasına göre canlandırılmıştır. Değerlendirme aşamasında ise öğrenciler hayvanların yaşam alanlarını anlatan bir afiş hazırlamışlardır.

Yedinci oturumunda; Yalanın Sonu adlı metin işlenmiştir. Hazırlık-Isınma aşamasında grupla iş birliğini gözeten etkinlikler yapılmıştır. Canlandırma aşamasında, metin olay sırasına göre canlandırılmıştır. Değerlendirme aşamasında ise öğrencilerin yaptıkları etkinliklerle metin arasında bir benzerlik olup olmadığı hakkında konuşulmuştur. Ardından öğrencilerin "Ben bugün ......... öğrendim.” cümlesini tamamlamaları istenmiştir.

Sekizinci oturumunda; Yalnızlığın Sonu metni işlenmiştir. Hazırlık-Isınma aşamasında Reklamını Yap, Să̆ Yanım Boş ve Neredesin? Buradayım oyunları oynanmıştır. Oyunlardan sonra Ara Değerlendirme alınarak, öğrencilere üç oyunun kuralları arasındaki benzerlik 
hakkında sorular sorulmuştur. Canlandırma aşamasında, metin olay sırasına göre canlandırılmıştır.

\subsection{4. İzleme Oturumlart}

Araştırmanın bu aşamasında yaratıcı drama etkinlikleri kullanılmamış, öğrenciler serbest bırakılarak grup içerisindeki öğrencilerle etkileşime girmeleri istenmiştir. Bu etkileşim sırasında öğrencilere İzleme Testi olarak “Görünmez Kaza” ve “Oyun Kartları” adlı metinler ve metinlere ait olan anlama soruları uygulanmıştır. Her bir uygulama 40'ar dakika sürmüş ve güvenirlik analizleri yapılabilmesi için kameraya kaydedilmiştir. Ardından araştırmacı ve iki alan uzmanı tarafından bu videoların hepsi izlenmiştir. Bu aşamada öğrencilerin metni okuduktan sonra yazılı ve sözlü olarak verdiği cevaplar, oluşturulan cevap anahtarına göre puanlanmıştır.

Şekil 1'de uygulama süreci ve süreçte kullanılan değerlendirme araçları gösterilmektedir.

\section{Şekil 1}

Uygulama Süreci ve Süreçte Kullanılan Değerlendirme Araçları

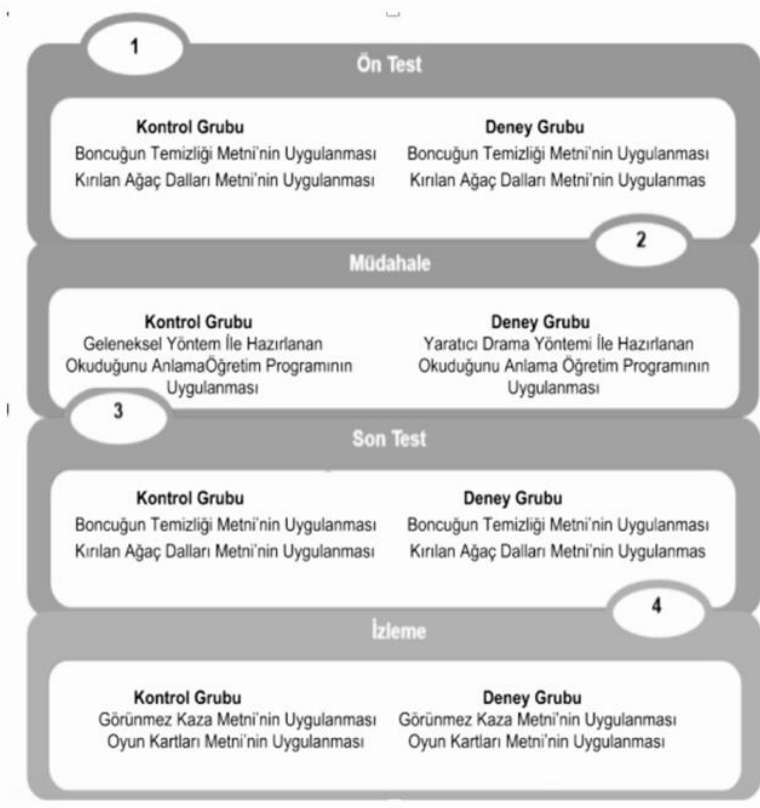




\subsection{Verilerin Analizi}

Araştırma kapsamında deney ve kontrol gruplarına eğitim-öğretim yılının başında ön test, deney grubuna OABÖP uygulandıktan sonra son test ve kalıcılığı belirlemek amacıyla da izleme testi yapılmıştır. Ön test ve son testte aynı metinler kullanılmasına rağmen, izleme testinde hatırlama etkisini ortadan kaldırmak amacı ile kapsam ve içerik açısından denk olan farklı iki metin kullanılmıştır. Böylece araştırmada yaratıcı drama eğitiminin öğrencilerin okuma becerileri üzerindeki etkisini belirlemek amacıyla, ön test, son test, izleme testi ve deney, kontrol gruplu 3x2' lik bir desen ortaya konulmuştur. Deney ve kontrol grubunda yer alan katılımcıların az sayıda olmaları nedeni ile parametrik tekniklerin varsayımları karşılanmamaktadır. Bu nedenle grupların ön test, son test ve izleme testi puanları arasında ve son test-ön test ile izleme-ön test fark puanları arasında istatistiksel olarak manidar bir fark olup olmadığg Mann Whitney U testi ile incelenmiştir. Ayrıca ilişkili ölçümlere ait puanlar arasındaki farkın anlamlılığını test etmek amacıyla Friedman testi kullanılmıştır. Ön test, son test ve izleme testinin grup içi faktörler, deney ve kontrol gruplarının ise gruplar arası faktörler olarak tanımlandığı araştırma deseninde belirtilen grup ve ölçümler Tablo 4’te gösterilmiştir.

\section{Tablo 4}

Araştırma Desenindeki Gözenekler

\begin{tabular}{llllll}
\hline & & \multicolumn{3}{c}{ Ölçüm } \\
\cline { 3 - 6 } & & $\mathrm{N}$ & Ön test & Son test & İzleme testi \\
\cline { 2 - 6 } Grup & Deney & 4 & $\mathrm{X}_{1}$ & $\mathrm{X}_{2}$ & $\mathrm{X}_{3}$ \\
& Kontrol & 4 & $\mathrm{X}_{1}$ & $\mathrm{X}_{2}$ & $\mathrm{X}_{3}$ \\
\hline
\end{tabular}

İki ilişkisiz gruptan elde edilen puanların birbirinden manidar bir şekilde farklılık gösterip göstermediğini test etmek amacıyla non-parametrik teknik olan Mann Whitey U testi yapılmıştır. Son test-ön test ile izleme testi-ön test fark puanları arasında istatistiksel olarak manidar bir fark olup olmadığı test edilmiştir. Bu yöntem ile farklı zamanlarda yapılan ölçümler 
arasındaki fark puanlarının gruplar arasında farklılaşıp farklılaşmadığı ortaya konulmuştur. Böylece deney ve kontrol grupları için farklı zamanlarda gerçekleştirilen ölçümler arasındaki farkların gruplar açısından istatistiksel olarak manidar bir fark oluşturup oluşturmadığı dikkate alınmıştır (Kirk, 2008; Tabachnick \& Fidell, 2013).

Ayrıca deney ve kontrol gruplarının ön test, son test ve izleme testi puanları arasında istatistiksel olarak manidar bir farklılık olup olmadığı incelenmiştir. Deney ve kontrol gruplarının her biri için art arda yapılan ölçümler (3 ölçüm) sonucu elde edilen puanlar arasında manidar bir fark olup olmadığını test etmek amacıyla yapılan non-parametrik teknik Friedman testidir. Friedman testinin anlamlı bulunması durumunda ise bonferroni düzeltmesi yapılarak üç ölçüm ikişerli olarak karşılaştırılmış ve Conover-Test yapılarak student $\mathrm{t}$ istatistiği yorumlanmıştır (Field, 2009; Green \& Salkind, 2005; Pohlert, 2018).

Deney ve kontrol grupları gibi farklı grup ortalamalarının karşılaştıııldığı analizlerde manidar bulunan hipotezler için sonucun pratikteki anlamlılığı etki büyüklüğünden yararlanılarak ortaya konulmaktadır. Böylece gruplar arasında bulunan farklılı̆̆ın önemine yönelik yorumlar yapılabilmektedir. Sonuçların yorumlanması sürecinde dikkate alınan etki büyüklüğü örneklem büyüklüğünden etkilenmemektedir ve böylece bağımsız değişkenin bağımlı değişken üzerinde ne düzeyde etkili olduğu ile ilgili daha doğru yorumlar yapılabilmektedir. İşaretine bakılmaksızın 0.0-0.2 arasında küçük, 0.2-0.5 arasında orta ve 0.5'den büyük ise geniş (büyük) etki büyüklügüü olarak ifade edilmektedir (Büyüköztürk, 2011; Can, 2013; Erkuş, 2011; Green \& Salkind, 2005; Tan, 2016). Araştırma kapsamında .05 anlamlılık düzeyi kabul edilmiş ve Excel 2013, SPSS 20.0 programları ve R programında "rstatix" ile "PMCMR" paketleri kullanılmıştır. 


\subsubsection{Araştırmanın Güvenirliğine İlişkin Veri Analizleri}

Bağımlı değişkene ilişkin yapılan güvenirlik analizlerinden biri olan gözlemciler arası güvenirlik; iki veya daha fazla sayıdaki bağımsız gözlemcinin birbirinden bağımsız ancak eşzamanlı olarak hedef davranışın ne düzeyde gerçekleştiğine ilişkin yaptıkları değerlendirmelerin karşılaştırılmasıdır (Kırcaali İftar \& Tekin, 2001).

Gözlemciler veya puanlayıcılar arası güvenirlik belirlemede tesadüfi hata kaynağı olarak puanlayıcılar/gözlemciler ele alınmaktadır. Puanlayıcılar arası uyumu belirlemeye yönelik olarak Krippendorff Alfa istatistiği kullanılabilmektedir. Puanlayıcı sayısı iki veya daha fazla veya ölçek türü sınıflama, sıralama, eşit aralıklı veya eşit oranlı olduğunda kullanılabilen Krippendorff Alfa tekniği, farklı puanlayıcı sayısına ve farklı ölçek türlerindeki verilere uygulanabilmesi nedeni ile kullanışlıdır. Krippendorff Alfa istatistiğindeki uyumun gücü 0.00-0.66 arası zayıf uyum, 0.670.79 arası orta düzey uyum, 0.80-1.00 arası ise yüksek uyum olarak yorumlanmaktadır (Hayes \& Krippendorff, 2007; Krippendorff, 1995, 2004a, 2004b).

$\mathrm{Bu}$ araştırmada deney ve kontrol gruplarına yerleşecek öğrencileri seçerken Okuduğunu Anlama Becerileri Kontrol Listesine göre öğrencilerin performansları 4 gözlemci/puanlayıcı tarafindan puanlanmıştır. Yapılan analizler sonucunda puanlayıcılar arası uyuşum yüzdelerinin 0.75 ile 0.96 arasında değiştiği bulunmuştur. Ayrıca araştırma sürecinde deney ve kontrol gruplarındaki öğrencilerin Okuduğu Metin İle İlgili Sorulara Cevap Verme Becerisine Yönelik Ölçme Formunda göre elde ettikleri ön test, son test ve izleme testlerindeki performansları 3 gözlemci/puanlayıcı tarafından puanlanmıştır. Yapılan analizler sonucunda puanlayıcılar arası uyuşum yüzdelerinin ön testlerde $0.68-1.00$, son testlerde, $0.73-1.00$ ve izleme testlerinde ise 0.75-1.00 arasında değiştiği ve puanlayıcılar arası uyuşumun orta düzey ve üzerinde olduğu ifade edilebilmektedir.

$\mathrm{Bu}$ araştırmada uygulama güvenirliğin sağlanması amacıyla da hem yaratıcı drama lideri hem de özel eğitim öğretmeni olan üç kişi, bağımsız gözlemci olarak seçilmiştir. Her bir 
öğrenciye ilişkin iki video kaydı bağımsız gözlemciler tarafından izlenmiş ve değerlendirilmiştir. Üç bağımsız gözlemci rastgele seçtikleri oturumları izlemiş, uygulama güvenirliği veri kayıt formuna kaydetmişlerdir.

Üç bağımsız uzmanın puanlamaları arasındaki tutarlılığın istatistiksel olarak belirlenmesi amacıyla ikiden fazla puanlayıcı arasındaki uyum düzeyine bakılması gerektiği durumlarda sınıflamalı ölçek düzeyindeki değişkenler için de kullanılabilen Krippendorff Alfa istatistiğinden yararlanılmıştır. Yapılan analizler sonucunda, Uygulama Güvenirliği Formu kullanılarak 3 bağımsız gözlemci/puanlayıcı tarafından yapılan puanlamalara ilişkin uyuşum yüzdesinin 0.73 olduğu bulunmuştur. Bu değer yapılan oturumları değerlendirmek amacıyla geliştirilen 14 maddeden oluşan Uygulama Güvenirliği Formunu dolduran 3 gözlemci/puanlayıcı arasındaki uyuşumun orta düzey olduğunu göstermektedir. Elde edilen bu güvenirlik değeri araştırmacının eğitim programını planladı̆̆ı şekilde uyguladığını göstermektedir.

\section{BULGULAR}

Yaratıcı drama eğitim programına devam eden deney grubu ile geleneksel yöntemde devam eden kontrol grubu öğrencilerinin okuma metinlerinden aldıkları ön test puanlarının sıra ortalamaları arasındaki fark Mann Whitney U testi kullanılarak incelenmiş ve bulgular Tablo 5'te verilmiştir.

\section{Tablo 5}

Ögrencilerin Ön Test Puanlarının Deney ve Kontrol Grubuna Göre Mann-Whitney U Testi Sописи

\begin{tabular}{lcccllll}
\hline & $\mathrm{n}$ & $\bar{X}$ & $\mathrm{~S} . \mathrm{S}$ & Sira Ortalaması & Sira Toplamı & $\mathrm{U}$ & $\mathrm{p}$ \\
\hline Deney Grubu & 4 & 65.75 & 7.89 & 5.25 & 21.00 & 5.00 & .384 \\
Kontrol Grubu & 4 & 62.00 & 7.96 & 3.75 & 15.00 & & \\
\hline
\end{tabular}


Tablo 5’te, hafif düzeyde zihinsel yetersizliği olan öğrencilerden yaratıcı drama yöntemi ile hazırlanan öğretim programını alarak deney grubunu oluşturan öğrencilerle böyle bir programa dahil olmayan öğrencilerin okuma metinlerinden aldıkları toplam ön test puanlarına göre yapılan Mann-Whitney U testi sonucu bulunmaktadır.

Çizelge incelendiğinde, deney ve kontrol grubundaki öğrencilerin okuma metinlerindeki ön test puanları arasında istatistiksel olarak manidar bir fark olmadığ görülmektedir $(\mathrm{U}=5.00, \mathrm{z}=-0.871, \mathrm{p}>.05)$. Sıra ortalaması dikkate alındığında da deney grubunda (5.25) ve kontrol grubunda olan öğrencilerin (3.75) sıra ortalamaları arasında manidar bir farklılığın olmadığı ifade edilebilmektedir. Bu bulgu ile çocukların grup farklılıklarının, okuma metinlerinden aldıkları ön test puanları üzerinde anlamlı bir etkisinin olmadığı söylenebilir.

Yaratıcı drama eğitim programına devam eden deney grubu ile geleneksel yöntemde devam eden kontrol grubu öğrencilerinin okuma metinlerinden aldıkları son test puanlarının sıra ortalamaları arasındaki fark Mann Whitney U testi kullanılarak incelenmiş ve bulgular Tablo 6'da verilmiştir.

\section{Tablo 6}

Ögrencilerin Son Test Puanlarının Deney ve Kontrol Grubuna Göre Mann-Whitney U Testi Sonucu

\begin{tabular}{lcccllll}
\hline & $\mathrm{n}$ & $\bar{X}$ & $\mathrm{~S} . \mathrm{S}$ & Sira Ortalamas1 & Sira Toplam1 & $\mathrm{U}$ & $\mathrm{p}$ \\
\hline Deney Grubu & 4 & 85.25 & 4.50 & 6.50 & 26.00 & 0.00 & $.020^{*}$ \\
Kontrol Grubu & 4 & 70.75 & 5.74 & 2.50 & 10.00 & & \\
\hline
\end{tabular}

$* \mathrm{p}<.05$

Tablo 6'da, hafif düzeyde zihinsel yetersizliği olan öğrencilerden yaratıcı drama yöntemi ile hazırlanan öğretim programını alarak deney grubunu oluşturan öğrencilerle böyle bir program almayan öğrencilerin okuma metinlerinden aldıkları toplam son test puanlarına göre yapılan Mann-Whitney U testi sonucu bulunmaktadır. 
Çizelge incelendiğinde, deney ve kontrol grubundaki öğrencilerin okuma metinlerindeki son test puanları arasında istatistiksel olarak manidar bir fark olduğu görülmektedir $(\mathrm{U}=0.00, \mathrm{z}=-2.323, \mathrm{p}<.05)$. Sıra ortalamaları dikkate alındığında da deney grubunda (6.50) ve kontrol grubunda olan öğrencilerin (2.50) sıra ortalamaları arasında manidar bir farklılığın olduğu ifade edilebilmektedir. Bu bulgu ile çocukların grup farklılıklarının, okuma metinlerinden aldıkları son test puanları üzerinde anlamlı bir etkisinin olduğu söylenebilir.

Ayrıca hesaplanan ' $U$ ' değerinin örneklem büyüklüğünden bağımsız bir şekilde, gerçekte (pratikte) bir anlam taşıyıp taşımadığını belirlemek amacıyla etki büyüklüğü hesaplanmıştır ( $r=|-0.82|, r>0.5$ ). Bulunan bu geniş (büyük) etki büyüklüğü, hafif düzeyde zihinsel yetersizliği olan öğrencilere uygulanan yaratıcı drama yönteminin deney grubundaki öğrencilerin okuma metinlerinden aldıkları son-test puanlarını olumlu yönde etkilediğini ortaya koymaktadır (Büyüköztürk, 2011; Field, 2009; Tan, 2016).

Yaratıcı drama eğitim programına devam eden deney grubu ile geleneksel yöntemde devam eden kontrol grubu öğrencilerinin okuma metinlerinden aldıkları izleme testi puanlarının sıra ortalamaları arasındaki fark Mann Whitney U testi kullanılarak incelenmiş ve bulgular Tablo 7'de verilmiştir.

\section{Tablo 7}

Ögrrencilerin İzleme Testi Puanlarının Deney ve Kontrol Grubuna Göre Mann-Whitney U Testi Sonucu

\begin{tabular}{lrrrrrrr}
\hline & $\mathrm{n}$ & $\bar{X}$ & $\mathrm{~S} . \mathrm{S}$ & Sira Ortalaması & Sira Toplamı & $\mathrm{U}$ & $\mathrm{p}$ \\
\hline Deney Grubu & 4 & 83.00 & 2.94 & 6.50 & 26.00 & 0.00 & $.021^{*}$ \\
Kontrol Grubu & 4 & 64.75 & 4.11 & 2.50 & 10.00 & & \\
\hline
\end{tabular}

$* p<.05$ 
Tablo 7'de hafif düzeyde zihinsel yetersizliği olan öğrencilerden yaratıcı drama yöntemi ile hazırlanan öğretim programını alarak deney grubunu oluşturan öğrencilerle böyle bir program almayan öğrencilerin okuma metinlerinden aldıkları toplam izleme testi puanlarına göre yapılan Mann-Whitney U testi sonucu bulunmaktadır.

Çizelge incelendiğinde, deney ve kontrol grubundaki öğrencilerin okuma metinlerindeki izleme testi puanları arasında istatistiksel olarak manidar bir fark olduğu görülmektedir $(\mathrm{U}=0.00, \mathrm{z}=-2.309, \mathrm{p}<.05)$. S1ra ortalamaları dikkate alındığında deney grubunda (6.50) ve kontrol grubunda olan öğrencilerin (2.50) sıra ortalamaları arasında manidar bir farklılığın olduğu ifade edilebilmektedir. Bu bulgu sonucunda çocukların grup farklılıklarının, okuma metinlerinden aldıkları izleme testi puanları üzerinde anlamlı bir etkisinin olduğu söylenebilir.

Ayrıca hesaplanan ' $U$ ' değerinin örneklem büyüklüğünden bağımsız bir şekilde, gerçekte (pratikte) bir anlam taşıyıp taşımadığını belirlemek amacıyla etki büyüklüğü hesaplanmıştır ( $r=|-0.82|, r>0.5$ ). Bulunan bu geniş (büyük) etki büyüklüğü, hafif düzeyde zihinsel yetersizliği olan öğrencilere uygulanan yaratıcı drama yönteminin deney grubundaki öğrencilerin okuma metinlerinden aldıkları izleme-testi puanlarını olumlu yönde etkilediğini göstermektedir (Büyüköztürk, 2011; Field, 2009; Tan, 2016).

Yaratıcı drama programına dahil olan deney grubundaki öğrencilerin okuma metinlerinden aldıkları ön test, son test ve izleme testi puanlarının sıra ortalamaları arasındaki fark Friedman testi kullanılarak incelenmiş ve bulgular Tablo 8'de verilmiştir. 


\section{Tablo 8}

Deney Grubundaki Öğrencilerin Tekrarlı Ölçümlerine İlişkin Friedman Testi Sonucu

\begin{tabular}{lcrrlcrlr}
\hline Deney Grubu & $\mathrm{n}$ & $\bar{X}$ & $\mathrm{~S} . \mathrm{S}$ & $\begin{array}{l}\text { Farkların } \\
\text { Ortalaması }\end{array}$ & $\begin{array}{c}\text { Sira } \\
\text { sd }\end{array}$ & $\chi^{2}$ & $\mathrm{p}$ \\
\hline Ön test & 4 & 65.75 & 7.89 & 1.00 & 2 & 7.60 & $.022^{*}$ \\
Son test & 4 & 85.25 & 4.50 & 2.88 & & & \\
İzleme Testi & 4 & 83.00 & 2.94 & 2.13 & & & \\
\hline
\end{tabular}

$* \mathrm{p}<.05$

Tablo 8'de, hafif düzeyde zihinsel yetersizliği olan öğrencilerden yaratıcı drama yöntemi ile hazırlanan öğretim programına dahil olarak deney grubunu oluşturan öğrencilerin tekrarlanan ölçümlerinin (ön test-son test-izleme testi) arasında fark olup olmadığı Friedman testi ile incelenmektedir.

Çizelge incelendiğinde, deney grubundaki öğrencilerin deney öncesinden sonrasına okuma metinlerinden aldıkları ön test, son test ve izleme testi puanlarının arasında istatistiksel olarak manidar bir fark olduğu görülmektedir $\left(\chi^{2}=7.60, \mathrm{sd}=2, \mathrm{p}<.05\right)$. Fark puanlarının sıra ortalamaları dikkate alındığında ön test (1.00), son test (2.88) ve izleme testi (2.13) için sıra ortalamaları arasında manidar bir farklılığın olduğu ifade edilebilir. Bu bulgu sonucunda deney grubundaki çocukların aldıkları eğitim programının, onların deney öncesinden sonrasına okuma metinlerinden aldıkları puanları üzerinde anlamlı bir etkisinin olduğu söylenebilir. Hangi iki ölçüm arasında anlamlı bir farklılaşma olduğunu belirlemek amacıyla ikili karşılaştırma yapılmıştır. Bu doğrultuda deney grubundaki öğrencilerin öntest ve sontest puanları arasında istatistiksel olarak anlamlı bir farklılaşma olduğu bulunmuştur $(\mathrm{t}=6.94, \mathrm{p}<.05)$. Benzer şekilde öğrencilerin öntest ve izleme testi puanları arasında istatistiksel olarak anlamlı bir farklılaşma olduğu söylenebilmektedir $(\mathrm{t}=4.16, \mathrm{p}<.05)$. Öğrencilerin sontest ve izleme testi puanları arasındaki farklılık ise istatistiksel olarak anlamlı değildir $(\mathrm{t}=2.77, \mathrm{p}>.05)$. Şekil 2'de verilen grafikte görüleceği üzere deney grubundaki öğrencilerin puan ortalamalarının deney 
öncesinden sonrasına artış gösterdiği ve deneyin bitmesiyle birlikte izleme testi puan ortalamasının sontest puanlarına yakın olduğu sonucuna ulaşılmıştır.

Kontrol grubundaki öğrencilerin okuma metinlerinden aldıkları ön test, son test ve izleme testi puanlarının sıra ortalamaları arasındaki fark Friedman testi kullanılarak incelenmiş ve bulgular Tablo 9'da verilmiştir.

\section{Tablo 9}

Kontrol Grubundaki Öğrencilerin Tekrarlı Ölçümlerine İlişkin Friedman Testi Sonucu

\begin{tabular}{lccclcccc}
\hline Kontrol Grubu & $\mathrm{n}$ & $\bar{X}$ & $\mathrm{~S} . \mathrm{S}$ & $\begin{array}{l}\text { Farkların } \\
\text { Ortalaması }\end{array}$ & Sira & sd & $\chi^{2}$ & $\mathrm{p}$ \\
\hline Ön test & 4 & 62.00 & 7.96 & 1.63 & 2 & 2.53 & .282 \\
Son test & 4 & 70.75 & 5.74 & 2.63 & & & \\
İzleme Testi & 4 & 64.75 & 4.11 & 1.75 & & & \\
\hline
\end{tabular}

Tablo 9'da, hafif düzeyde zihinsel yetersizliği olan öğrencilerden geleneksel yöntemle hazırlanan öğretim programına dahil olarak kontrol grubunu oluşturan öğrencilerin tekrarlanan ölçümlerinin (ön test-son test-izleme testi) arasında fark olup olmadığı Friedman testi ile incelenmektedir.

Tablo 9 incelendiğinde, kontrol grubundaki öğrencilerin deney öncesinden sonrasına okuma metinlerinden aldıkları ön test, son test ve izleme testi puanlarının arasında istatistiksel olarak manidar bir fark olmadığı görülmektedir $\left(\chi^{2}=2.53, \mathrm{sd}=2, \mathrm{p}>.05\right)$. Fark puanlarının sıra ortalamaları dikkate alındığında da ön test (1.63), son test (2.63) ve izleme testi (1.75) için sıra ortalamaları arasında manidar bir farklılı̆gın olmadığı ifade edilebilir. Bu bulgu sonucunda kontrol grubundaki öğrencilerin deney öncesinden sonrasına okuma metinlerinden aldıkları puanları farklılaşmamıştır. Deney ve kontrol grubundaki öğrencilerin çalışma öncesi sonrası ve izleme testi sonucunda aldıkları puanların ortalamaları grafik Şekil 2'de verilmiştir. 


\section{Şekil 2}

Ögrrencilerin Ön, Son ve İzleme Testi Sonunda Aldıkların Puanların Ortalamaları

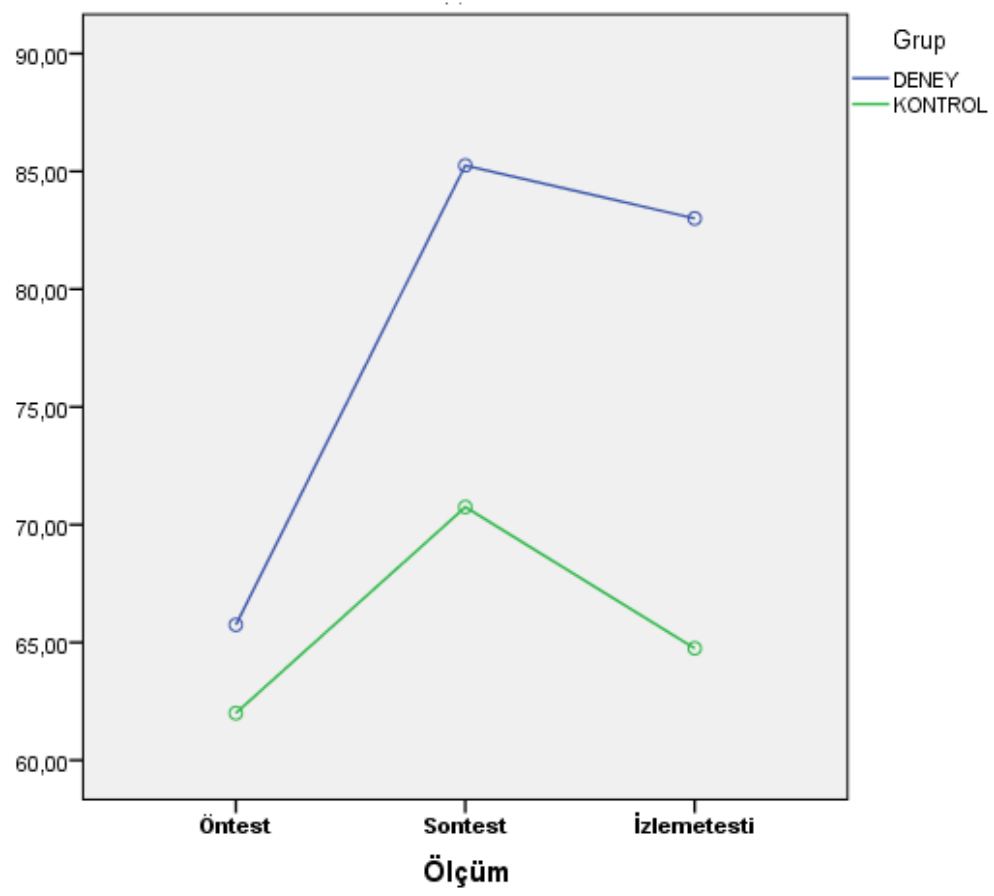

Şekil 2’de, deney ve kontrol gruplarındaki öğrencilerin deney öncesinden sonrasına geçen süredeki okuma becerileri puan ortalamaları verilmiştir. $\mathrm{Bu}$ puan ortalamaları incelendiğinde; yaratıcı drama yönteminin deney grubunda yer alan öğrencilerin, metinle ilgili sorulara cevap verme becerilerine olumlu etki ettiği gözlemlenmektedir.

\section{TARTIŞMA}

Hafif düzeyde zihinsel yetersizliği olan öğrencilere yaratıcı drama yöntemi yoluyla okuduğunu anlama becerileri öğretimi amaçlanan bu çalışmada, deney grubunda yer alan öğrencilerin, OABÖP’ye katılımları sonrasında metinlere ilişkin okuduğunu anlama sorularını daha iyi kavradıkları gözlemlenmiştir. Bu öğrencilerin bir metni okuduklarında, metnin içeriğini anlayabildikleri zaman metinden daha fazla zevk aldıkları ve metnin içeriğini unutmadıkları görülmüştür. Okunan bir metni anlama eğitiminde, öğrenciler metnin içeriğini (olayın geçtiği yer, başlatıcı olaylar, iç tepkiler, amaçlar, çabalar ve sonuçlar) tanımlamayı ve bu içeriğin konu içerisinde nasıl işlendiğini okuduğunu anlama soruları yardımıyla 
öğrenmektedirler.

Adomat (2009)'a göre, yaratıcı drama yöntemi metin ile etkileşimde ve bu metni anlama becerilerinde önemli derecede etkilidir. Öğrenciler kendi ilgi alanlarını ve güçlü oldukları yönlerini kullanarak, yaratıcı drama yoluyla metin hakkında kişisel yorum yapabilmekte ve metinlerdeki anlamla ilgili sosyal bağlam geliştirebilmektedirler. Metinleri somut, çok yönlü tekniklerle öğrenip, metinlerle etkileşim kurmaktadırlar. $\mathrm{Bu}$ durum, yaratıcı dramanın öğrenmenin gerçekleşmesine yardımcı olmak için güçlü bir ortam sağladığını göstermektedir (Booth, 1985). Yaratıcı dramanın etkileşimli ve katılımcı olması, öğrencilerin grupla birlikte tartışarak, metni anlamaya doğru ilerlemelerini sağlamıştır.

Eripek (2009)'e göre, zihinsel yetersizliği olan öğrencilerin başarısızlık beklentileri yüksek olduğunda öğrenme durumlarında bulunan çaba azalmakta dolayısıyla çocuğun performansı yapabileceğinin altına düşmektedir. Bu araştırmanın başlangıcında da araştırmaya katılan öğrencilerde, öğrencilerin öğrenme durumlarında art arda yaşadıkları yoğun başarısızlıklardan dolayı güdülenmelerinin düşük olduğu, buna bağlı olarak başarısızlık beklentilerinin de yüksek olduğu gözlemlenmiştir.

Rose ve diğerleri (2000)'ne göre yaratıcı drama eğitim stratejileri, öğrencilerin metni derinlemesine keşfetmelerini, metinden zevk alarak anlamalarını desteklemekte ve okuma motivasyonlarına olumlu katkılar sağlamaktadır. Bu etkinlikler, öğrencilerin hikâyeye ilgi duymalarına, hikâyeyle ilgili tahmin yapmalarına, hikâyenin arka planı hakkında bilgi edinmelerine yardımcı olmakta ve bu sayede çocukları okumaya hazırlamaktadır (Akt; Kelin, 2007). Araştırmada deney grubunda yer alan öğrencilerin yaratıcı drama yolu ile hem motivasyonlarının hem de işlenen metne karşı ilgilerinin arttığı gözlemlenmiştir.

McCaslin (1990)'e göre yaratıcı drama yöntemi, öğrencilerin ilk defa duydukları sözcükleri öğrenmelerine yardımcı olmaktadır (Akt; Arnas vd., 2007). Araştırma sürecinde 
öğrenciler daha önce bilmedikleri yeni sözcüklerle karşılaşmışlardır. Yaratıcı drama yolu ile deney grubuna katılan öğrencilerin sözcük dağarcıklarının gelişimi de desteklenmiştir.

Bayhan ve Yükselen (2006)'e göre, yaratıcı drama grubuna katılan öğrencilerin yaratıcı drama yoluyla hazırlanan etkinliklerde dikkatli bir şekilde ve düşünme hızlarına uygun olarak yönlendirildiğinde; metinleri canlandırmaya hazır hale geldikleri gözlemlenmiştir. Araştırmada metinleri yaratıcı drama yoluyla planlama, canlandırma ve destekleme aşamalarında, görevler ve süreç normal gelişim gösteren öğrencilere göre daha basit hazırlanmış ve uygulamalar gelişimi normal olan öğrencilere göre daha uzun sürmüştür. Özellikle uygulama için seçilen metinler basit, açıkça anlaşılır ve ilgilerini çeken nitelikte hazırlanmıştır. Öğrencilerin ilgi alanlarını genişleten, ifade edebilecekleri yeni sözcükler içeren farklı metinlere yer verilmiştir.

Uşaklı (2007)'ye göre süreç içerisinde öğrencilerin aldıkları roller, onların duyuşsal, psikomotor ve zihinsel becerilerini ortaya koymalarına yardım etmekte ve bu sayede öğrenilen konularda bütünlük sağlanabilmektedir. Araştırma sonucunda, deney grubunda yer alan öğrencilerin etkinliklere katılımlarının arttığı gözlemlenmiştir. Yaratıcı drama sürecinde rol oynama, öğrencilerin yeni davranış ve becerileri uygulayabilmeleri için onlara güvenli bir ortam sağlamıştır. Aynı zamanda öğrencilerin oyun oynayarak, role girerek, grupla birlikte ortak hareketler tasarlayarak, resim - afiş yaparak, yazarak, okuyarak yaptıkları etkinlikler onların bir mekâna bağlı kalmamasını sağlamıştır. Bu durum öğrencilerin beş duyularını da kullanmalarına olanak vermiş, bu sayede etkili öğrenme ortamı oluşmuştur.

\section{SONUÇ VE ÖNERİLER}

$\mathrm{Bu}$ araştırmada, hafif düzeyde zihinsel yetersizliği olan öğrencilerle yaratıcı drama yoluyla okuduğu metin ile ilgili sorulara cevap verme becerileri öğretimi çalış1lmıştır. Geleneksel yönteme alternatif bir yöntem olarak yaratıcı drama yöntemi ile yapılan bu çalışmada, yaratıcı drama yönteminin öğrencilerin okuduğunu anlama becerilerinden biri olan metinle ilgili sorulara cevap verme becerilerine olumlu etki ettiği gözlemlenmiştir. 
Araştırmada yer alan deney grubu öğrencilerinin yaratıcı drama oturumlarında işlenen metinleri grup halinde okumaları ve tartışmaları okunan metni daha iyi anlamalarını sağlamıştır. $\mathrm{Bu}$ oturumlarda kullanılan oyunlarla, metinlerde işlenen konuların bağlantılı olması, metinlerde işlenen konuların öğrencilerin hafızalarında kalmalarını sağlamıştır. Aynı zamanda öğrenciler metinlerdeki bu konuları grup olarak canlandırdıkları için konulardaki durumları deneyimlemişlerdir. Öğrenciler deneyimledikleri bu durumları yaşantıya dönüştürdükleri için hafizalarında daha kalıcı öğrenmeler oluşmuştur.

Araştırmada öğrenciler metinleri grup halinde okuyup, grup halinde oyunlar oynayıp, grup halinde değerlendirmelere katıldıkları için öğrencilerde iş birliği içinde öğrenme, yardımlaşma, birbirlerinin fikirlerini dinleme, konuşmak için söz alma ve birbirlerini bekleme davranışlarında olumlu gelişmeler gözlemlenmiştir. Kazanılan bu davranışlar sayesinde, öğrencilerin metin hakkındaki düşüncelerini daha özgür ve cesaretli bir şekilde ifade etmelerine olanak sağlamıştır. Aynı zamanda yaratıcı drama oturumlarında sık sık yer alan ara değerlendirmeler; öğrencilerin metinden kopmamasına, metinle ilgili bağlantıları çoğaltmalarını sağlamış, metinle ilgili soruların cevaplarına odaklanmaları için yönlendirici olmuştur. Yaratıcı drama oturumları sonrasında yapılan değerlendirmelerle de metnin bütünü hakkında fikir oluşturmalarına yardımcı olmuştur.

Araştırmada yer alan yaratıcı drama oturumlarının kazanımları sayesinde öğrenciler günlük yaşantılarında karşılaşabilecekleri problem durumlarını da metinler yoluyla deneyimlemişlerdir. Metinlerin içeriğinde yer alan problem durumları öğrencilerin arkadaşlarıyla yaşadığı, çoğu zaman bireysel olarak çözemeyip, yetişkin desteğiyle çözdüğü konuları içermektedir. Öğrenciler metinlerde yer alan bu problem durumlarını gruplarda canlandırmış ya da başka bir grubun canlandırmasını izlemiş, bu canlandırmalar hakkında tartışıp, çözüm yolları üretebilmişlerdir. Öğrenciler bu durumları yaratıcı drama sayesinde yaşantıyla deneyimlemişler, yaşadıkları problem hakkında çözüm önerilerine de sahip 
olmuşlardır. Öğrencilerin bu kurgusal ortamda yaşantıyla deneyimledikleri problem durumlarının çözümleri, gerçek yaşamlarında da öğrencilere kolaylık sağlayacaktır.

$\mathrm{Bu}$ açıdan bakıldığında, yaratıcı drama yoluyla oluşturulan OABÖP, hafif düzeyde zihinsel yetersizliği olan öğrenciler üzerinde olumlu yönde etkili olmuş ve öğrencilerin metin ile ilgili sorulara cevap verme becerilerini geliştirmiştir. Metinlerin uygulandığg kişi sayısının az olması nedeni ile araştırmada kullanılan ölçme araçlarının yapı geçerliği, uzman görüşlerine dayalı olarak sezgisel yöntemlerle belirlenmiştir. Bu durum, araştırmanın bir sınırlılı̆̆ıdır. Yaratıcı drama yöntemi bu öğrencilerin öğrenme şekillerini aynı zamanda birbirleriyle olan sosyal etkileşimlerini de arttırdığg için Türkçe, Matematik, Toplumsal Yaşam Becerileri gibi farklı disiplinlerde bir yöntem olarak daha aktif kullanılabilir. Hafif düzeyde zihinsel yetersizliği olan öğrenciler için hazırlanan OABÖP farklı yetersizlik gruplarında ve farklı yaşlarda bulunan öğrencilerde uygulanarak etkililiği denenebilir.

\section{KAYNAKLAR}

Aaron, P. G. (1995). Introduction to mini-series: Recent advances in reading instruction and remediation. School Psychology Review, 24(3), 327-330. https://doi.org/10.1080/02796015.1995.12085771

Adıgüzel, Ö. (2006). Yaratıcı drama kavramı, bileşenleri ve aşamaları. Yaratıcı Drama Dergisi, l(1), 17-30.

Adıgüzel, Ö. (2006). Yaşantılara dayalı öğrenme, yaratıcı drama ve süreçsel drama ilişkileri. Yaratıcı Drama Dergisi, 1(1), 31-38.

Adıgüzel, Ö. (2010). Eğitimde yaratıcı drama. Naturel Yayıncılık.

Adomat, D. S. (2009). Actively engaging with stories through drama: Portraits of two young readers. The Reading Teacher, 62(8), 628-636. https://doi.org/10.1598/RT.62.8.1 
Al Otaiba, S., \& Fuchs, D. (2002). Characteristics of children who are unresponsive to early literacy intervention: A review of the literature. Remedial and Special education, 23(5), 300-316. https://doi.org/10.1177\%2F07419325020230050501

Arbay, B., \& Akfirat, F. Ö. (2012). Yaratıcı Drama Yöntemi ile İşitme Engelli Çocuklarda Sosyal Beceri Geliştirme. Yaratıcı Drama Dergisi, 7(14), 48-62.

Akfirat, F. Ö. (2004). Yaratıcı dramanın işitme engellilerin sosyal becerilerinin gelişimine etkisi (Yayın No. 141444) [Doktora tezi, Ankara Üniversitesi]. YÖK. https://tez.yok.gov.tr

Akyol, H. (2011). Yeni programa uygun Türkçe öğretim yöntemleri. Pegem Akademi.

Armbruster, B. B., Lehr, F., Osborn, J., O’Rourke, R., Beck, I., Carnine, D., \& Simmons, D. (2001). Put reading first. National Institute for Literacy.

Arnas, Y. \& Adigüzel, Ö. (Ed.). (2020). Erken çocukluk eğitiminde drama içinde (ss. 2-18). Pegem Akademi.

Arnas, Y. A., Cömertpay, B., \& Sofu, H. (2007). Altı yaş grubu çocukların dil kullanımına yaratıcı dramanın etkisi. Yaratıcı Drama Dergisi C, 1, 3-4.

Babudoh, G. B. (2014). Enhancing Literacy Skills of Students with Congenital and Profound Hearing Impairment in Nigeria Using Babudoh's Comprehension Therapy. Journal of the International Association of Special Education, 15(1).

Bayhan, P. (1985). Zihinsel özürlü çocuklarda drama. Ankara Üniversitesi Eğitim Bilimleri Fakültesi Özel Ĕ̈itim Dergisi, 2(01).

Bayhan, P., \& Yükselen, A. (2007). Özel gereksinimli çocuklarda drama modelleri ve oyun. Yaratıcı Drama Dergisi, 1(3/4), 45-56.

Blachman, B. A. (1994). What we have learned from longitudinal studies of phonological processing and reading, and some unanswered questions: A response to Torgesen, 
Wagner, and Rashotte. Journal of learning disabilities, 27(5), 287-291. https://doi.org/10.1177\%2F002221949402700504

Booth, D. (1985). "Imaginary gardens with real toads": Reading and drama in education. Theory $\quad$ into $\quad$ Practice, $\quad 24(3), \quad$ 193-198. https://doi.org/10.1080/00405848509543172

Brady, S. A. (1997). Ability to encode phonological representations: An underlying difficulty of poor readers. In B. A. Blachman (Ed.), Foundations of reading acquisition and dyslexia: Implications for early intervention (pp. 21-47). Lawrence Erlbaum Associates Publishers.

Büyüköztürk, Ş. (2011). Sosyal bilimler için veri analizi el kitabı (14. Baskı). Pegem A Yayıncilık.

Büyüköztürk, Ş., Kılıç-Çakmak, E., Akgün, Ö.E., Karadeniz, Ş., \& Demirel, F. (2014). Bilimsel araştırma yöntemleri. Pegem Akademi.

Büyüköztürk, Ş.(2001). Deneysel desenler. Pegem Yayınc1lık.

Can, A. (2013). SPSS ile bilimsel araştırma sürecinde nicel veri analizi. Pegem Akademi.

Cora İnce, N. (2007). Zihinsel engelli öğrencilere okuduğunu anlama becerilerinin ögretilmesinde işbirlikli öğrenme yaklaşımı ile sunulan öğretim programının etkililiğinin incelenmesi (Yayın No. 234260) [Doktora tezi, Ankara Üniversitesi]. YÖK. https://tez.yok.gov.tr

Coşkun, İ., Gür, T., \& Aykutlu, H. (2014). Hafif düzeyli zihin engelli bireylerin okuduğunu anlama düzeyinin belirlenmesi ve yorumlanması amacıyla metin sonrası çizilen resimlerin incelenmesi. International Journal Of Eurasia Social Sciences, 2014(14), $17-42$. 
Çetrez İşcan, G., \& Coşkun, İ. (2016). Okuma stratejilerinin hafif derecedeki zihinsel yetersizliği olan bir öğrencinin akıcı konuşmasına ve anlama düzeyine etkisi. Turkish Studies (Elektronik), 11(3), 821-846.

Çolak, Y. (2019). Disleksi teşhisi konmuş çocuklara drama ile okuma yazma öğretimi. Kesit Akademi Dergisi, (20), 225-243.

Dağlı Gökbulut, Ö., Akçamete, G., \& Güneyli, A. (2020). Birlikte öğretim uygulamalarının özel gereksinimli ilkokul öğrencilerinin okuduğunu anlama becerilerine etkisi. Elektronik Sosyal Bilimler Dergisi, 19(74). https://doi.org/10.17755/esosder.592673

Deliveli, K. (2020). Zihinsel yetersizliği olan öğrencilere okuma-yazma öğretilirken karşılaşılan güçlükler ve geliştirilen stratejiler. Electronic Turkish Studies, 15(2). http://dx.doi.org/10.29228/TurkishStudies.39883

Dibek, E. (2003). 7-11 yaş öğretilebilir zihinsel engelli çocuklarda eğitici dramanın kelime kazanımına etkisi (Yayın No. 261968) [Yüksek lisans tezi, Marmara Üniversitesi]. YÖK. https://tez.yok.gov.tr

Diken, H. İ., \& Cavkaytar, A. (2007). Özel eğitime giriş. Kök Yayıncılık.

Doğanay Bilgi, A. (2009). Zihinsel yetersizliği olan ögrencilerin bilgi veren metinleri anlamalarında uyarlanmış çok ögeli bilişsel strateji öğretiminin etkililiği (Yayın No. 278304) [Doktora tezi, Gazi Üniversitesi]. YÖK. https://tez.yok.gov.tr

Duman, N. (2006). Hikaye haritası yönteminin ĕgitilebilir zihinsel engelli öğrencilerin okuduğunu anlama becerileri üzerindeki etkisi (Yayın No. 188034) [Yüksek lisans tezi, Abant İzzet Baysal Üniversitesi]. YÖK. https://tez.yok.gov.tr

Eripek, S. (2009). Zihinsel yetersizliği olan çocuklar. Ataman, A (Ed.), Özel gereksinimli çocuklar ve özel eğitime giriş (ss.107-140). Gündüz Eğitim ve Yayıncılık.

Erkuş, A. (2011). Davranış bilimleri için bilimsel araştırma süreci. Seçkin Yayıncılık. 
Field, A. (2009). Discovering statistics using SPSS (and sex and drugs and rock ' $n$ ' roll) (Third edition). Sage Publications Ltd.

Green, S. B., \& Salkind, N. J. (2012). Using SPSS for Windows and Macintosh: Analyzing and understanding data. Prentice-Hall.

Güler, Ö. (2008). Zihinsel engelli öğrencilerin okuduğunu anlama becerisinde okuma öncesi, sırası ve sonrasında uygulanan okuduğunu anlama tekniklerinin etkililiklerinin karşılaştırılması (Yayın No. 218469) [Yüksek lisans tezi, Gazi Üniversitesi]. YÖK. https://tez.yok.gov.tr

Güneş, F. (2021). Anlama öğretimi. Pegem Akademi.

Güzel, R. (1998). Alt özel sınıflardaki öğrencilerin sesli okudukları öyküyü anlama becerilerini kazanmalarında doğrudan ögretim yöntemiyle sunulan bireyselleştirilmiş okuduğunu anlama materyalinin etkililiği (Yayınlanmamış Doktora Tezi). Gazi Üniversitesi, Ankara.

Hartman, K. D., Akyol, H., \& Baş, Ö. (2021). Anlama stratejileri dijital etkinlikler ile dört temel dil becerisi. Pegem Akademi.

Hayes, A. F., \& Krippendorff, K. (2007). Answering the call for a standard reliability measure for coding data. Communication methods and measures, 1(1), 77-89. https://doi.org/10.1080/19312450709336664

Ilter, I. (2018). Zayıf okuyucuların okuduğunu anlama becerilerinin geliştirilmesinde ana fikir belirleme becerisinin öğretimi. Ankara Üniversitesi Eğitim Bilimleri Fakültesi Özel Ĕ̆itim Dergisi, 19(2), 303-334. https://doi.org/10.21565/ozelegitimdergisi.315887

İpek, A. (1998). Eğitimde dramanın zihinsel engelli çocukların sosyal gelişimleri üzerinde etkisinin incelenmesi (Yayın No. 70440) [Yüksek lisans tezi, Hacettepe Üniversitesi]. YÖK. https://tez.yok.gov.tr 
Kalkan, S. (2009). Özel eğitim sınıfları ile birlikte eğitim ortamlarına devam eden, zihinsel yetersizlikten etkilenmiş öğrencilerin okuduğunu anlama, okuma hızları ve okuma hatası performanslarının karşılaştırılması. Journal of Current Researches on Educational Studies, 1(1), 38-50.

Kangal, S. B. (2010). Normal ve üstün yetenekli çocukların ahlaki yargılarının karşılaştırılması ve yaratıcı drama programının çocukların ahlaki yargılarına etkisi (Yayın No. 267402) [Doktora tezi, Hacettepe Üniversitesi]. YÖK. https://tez.yok.gov.tr

Kargın, T., Güldenoğlu, B., \& Ergül, C. (2017). Dinlediğini anlama becerisinin okuduğunu anlama üzerindeki yordayıcılı̆̆ının incelenmesi. Kastamonu Eğitim Dergisi, 25(6), 2369-2384.

Kaya, D., \& Eratay, E. (2009). Yetişkin zihin engelli bireylerin sosyal becerilerinin gelişiminde yaratıcı drama yönteminin etkililiğinin incelenmesi. Yaratıcı Drama Dergisi, 4(8), 5374.

Kelin, D. A. (2007). The perspective from within: Drama and children's literature. Early Childhood Education Journal, 35(3), 277-284. http://dx.doi.org/10.1007/s10643-0070206-3

Kırcaali İftar, G., \& Tekin, E. (2001). Özel eğitimde yanlışsız ögretim yöntemleri. Nobel Yayın Dağıtım.

Kirk, R. E. (2008). Statistics an introduction (5th edition). Thomson Higher Education.

Krippendorff, K. (1995). On the reliability of unitizing continuous data. Sociological Methodology, 47-76. http://dx.doi.org/10.2307/271061

Krippendorff, K. (2004a). Measuring the reliability of qualitative text analysis data. Quality and quantity, 38, 787-800. https://doi.org/10.1007/s11135-004-8107-7

Krippendorff, K. (2018). Content analysis: An introduction to its methodology. Sage publications. 
Kudret, Z. B., \& Baydık, B. (2016). Başarılı ve başarısız dördüncü sınıf okuyucularının okuduğunu anlama ve özetleme becerileri. Ankara Üniversitesi Ĕgitim Bilimleri Fakültesi Ö̈zel Eğitim Dergisi, 17(03), 317-346. https://doi.org/10.21565/ozelegitimdergisi.268558

Kutlu, Ö., Doğan, D., \& Karakaya, İ. (2010). Öğrenci başarısının belirlenmesi performansa ve portfolyoya dayalı durum belirleme. Pegem Akademi.

McCaslin, N. (1990). Creative drama in the classroom. Addison-Wesley Longman Limited.

McMaster, J. C. (1998). " Doing" literature: Using drama to build literacy. The reading teacher, 51(7), 574-584.

Ovayurt, B. Z., \& Akfirat, F. Ö. (2016). Zihinsel yetersizligi olan genç bireylerde atilganlik becerilerinin yaratici drama yöntemi ile gelistirilmesi*/development of sssertiveness skills of young individuals with mental deficiencies with the help of creative drama method. Yaratici Drama Dergisi, 11(2), 83. DOI:10.21612/yader.2016.013

Ömeroğlu, E. (1992). Okul öncesi işitme engelli çocukların kaynaştırılmasında yaratıcı drama eğitimin kullanılması. Ankara Üniversitesi Eğitim Bilimleri Fakültesi Özel Ĕ̆itim Dergisi, 1(02).

Önemli, M., Totan, T., \& Abbasov, A. (2015). Yaratıcı drama eğitiminin özel gereksinimli olan çocukların sosyal beceri alanlarından konuşma ve ilişki kurma becerilerine katkısı. Asya Ögretim Dergisi, 3(1), 50-65.

Özak, H. Y. (2017). Zihinsel yetersizliği olan öğrencilere okuduğunu anlama becerilerinin ögrretiminde uyarlanmış bilişsel strateji öğretiminin etkililiği (Yayın No. 468270) [Doktora tezi, Ankara Üniversitesi]. YÖK. https://tez.yok.gov.tr

Özbay, M. (2006). Okuma eğitiminde çevre faktörü. Eurasian Journal of Educational Research, 24, 161-170. 
Park, K. (1998). Focus on practice: dickens for all: inclusive approaches to literature and communication with people with severe and profound learning disabilities. British Journal of Special Education, 25(3), 114-118. https://doi.org/10.1111/1467-8527.t01$1-00070$

Pişkin, Ü. (1993). Otistik çocuklarda oyun. Ankara Üniversitesi Ĕgitim Bilimleri Fakültesi Özel Eğitim Dergisi, 1(03). https://doi.org/10.1501/Ozlegt_0000000016

Podlozny, A. (2000). Strengthening verbal skills through the use of classroom drama: A clear link. Journal of Aesthetic education, 34(3/4), 239-275. https://doi.org/10.2307/3333644

Pohlet, T (2018). Calculate pairwise multiple comparisons of mean rank sums. R package version 4.3. https://cran.r-project.org/web/packages/PMCMR/PMCMR.pdf

Rose, D. S., Parks, M., Androes, K., \& McMahon, S. D. (2000). Imagery-based learning: Improving elementary students' reading comprehension with drama techniques. The Journal of Educational Research, 94(1), 55-63. https://doi.org/10.1080/00220670009598742

Sanır, H., Akçayır, I., \& Özkubat, U. (2020). Determining the effect of intervention and intervention packages on the reading fluency and comprehension of lower secondary school students with mental retardation. Eğitim ve Bilim, 45(204), 207-225. http://dx.doi.org/10.15390/EB.2020.8828

Şenel, H. G. (1998). Okuma güçlüğü olan ve olmayan ilkokul öğrencilerinin okuma düzeylerinin ve dislektik özelliklerinin karşılaştırılması (Yayın No. 72424) [Doktora tezi, Ankara Üniversitesi]. YÖK. https://tez.yok.gov.tr

Tabachnick, B. G., \& Fidell, L. S. (2013). Using multivariate statistics: International edition. Pearson. 
Tahiroğlu, M. (2014). Değerler eğitimi yöntemleriyle desteklenen bir akıcı okuma ve okuduğunu anlama çalışması. Electronic Turkish Studies, 9(8), 793-811. https://doi.org/10.7827/TurkishStudies.7377

Tallal, P. (1990). Fine-grained discrimination deficits in language-learning impaired children are specific neither to auditory modality nor speech perception. Journal of Speech and Hearing Research, 33, 616-617. https://doi.org/10.1044/jshr.3303.616

Tan, Ş. (2016). SPSS ve excel uygulamalı temel istatistik-1. Pegem Akademi.

Torgesen, J. K., Wagner, R. K., \& Rashotte, C. A. (1994). Longitudinal studies of phonological processing and reading. Journal of learning Disabilities, 27(5), 276-286. https://psycnet.apa.org/doi/10.1177/002221949402700503

Tüfekçi, A. (2007). Yaratıcı drama yoluyla kaynaştırma programındaki engelli ergenlerde duygu durumlarını algılama ve ifade etme (Yayınlanmamış Yüksek Lisans Projesi) Ankara Üniversitesi Eğitim Bilimleri Enstitüsü, Ankara.

Uşaklı, H. (2007). Drama ve iletişim becerileri. Nobel Yayıncılık. 


\section{EXTENDED ABSTRACT}

The primary purpose of this quasi-experimental study is to determine whether a creative drama program prepared for teaching reading comprehension skills (the Reading Comprehension Skills Instruction Program - RCSIP) significantly improves the reading comprehension skills of students with mild intellectual disabilities. Specifically, the research questions asked whether there was a significant difference between the pre-test, post-test, and follow-up test that the study group, receiving creative drama and control group receiving traditional method, and between at least two of the pre-test, post-test and follow-up test scores that these study and control group students received from the texts they read.

The study employed a paired pre-test-post-test control group pattern. Data were collected via the Reading Comprehension Skills Checklist and Audible Reading Test in choosing the students, the reading passages (texts) and Data Recording Forms for the Skill of Answering the Questions About the Text Reading in the implementation phase were used.

The experimental group received RCSIP integrated with creative drama over eight sessions. During this period, the control groups were administered eight reading texts and comprehension questions the conventional method. A Follow-up Session was held three weeks following the completion of the program.

Mann-Whitney U test was used to analyze whether there was a statistically significant difference between the pre-test, post-test, and follow-up test scores of the groups and between the post-pre-test and follow-up-pre-test difference scores. The Friedman test was used to test the significance of the difference between the related measures scores. In case the Friedman test was found to be significant, a post-hoc Benferroni correction was made, comparing the three measurements in pairs of two, performing a Conover-Test, and making interpretations by student's t-test. The study data were analyzed to determine the effectiveness of the creative 
drama education program and the reliability of the research. It conducts Reliability Analysis Among Observers (Raters) and Application Reliability Analysis for research reliability.

Results revealed no statistically significant difference between the pre-test scores in the students' reading texts in the experimental and control groups $(U=5.00, \mathrm{z}=-0.871, \mathrm{p}>.>05)$. This suggests that the children's group differences did not significantly affect their pre-test scores from reading texts.

A statistically significant difference was observed between the students' post-test scores in the experimental and control groups in their reading texts $(U=0.00, \mathrm{z}=-2.323, \mathrm{p}<.05)$. A significant difference was also observed between the students' mean rank in the experimental group (6.50) and the control group (2.50). This suggests that children's group differences significantly affected their post-test scores from reading texts.

We observe a statistically significant difference between the students' follow-up test scores in the experimental and control groups in their reading texts $(U=0.00, z=-2.309, p$ $<.05)$. Considering the mean ranks, we observe a significant difference between the students' mean rank in the experimental group (6.50) and the control group (2.50). We can note that children's group differences significantly affect their follow-up test scores from reading texts per this finding. The calculated large effect size $(r=-0.82), 82 \%$ of the observed variance (variability) in the follow-up test scores of the groups can be explained by the differentiation of the programs.

A statistically significant difference was found between at least two of the pre-test, posttest, and follow-up test scores that the students in the experimental group received from the reading texts before and after the experiment $\left(\chi^{2}=7.60, \mathrm{sd}=2, \mathrm{p}<.05\right)$. There was a significant difference between the mean ranks for the pre-test (1.00), post-test (2.88), and follow-up test (2.13). The finding suggests that the instructional program that the children in the experimental group received had a significant effect on their pre-experiment and post-experiment reading 
scores. A paired comparison was made to determine the two measurements that had a significant difference. Accordingly, a statistically significant difference was found between the pretest and posttest scores of the students in the experimental group $(\mathrm{t}=6.94, \mathrm{p}<.05)$. Similarly, there was also a statistically significant difference between their pretest and follow-up test scores $(\mathrm{t}=4.16, \mathrm{p}<.05)$. However, the posttest and follow-up test scores did not differ with a statistical significance $(t=2.77, \mathrm{p}>.05)$. As seen in the graph in Figure 2, the mean scores of the experimental group increased from throughout the procedure. The mean follow-up test score approached the posttest scores as the experiment ended.

There were no no statistically significant difference between at least two of the pre-test, post-test, and follow-up test scores that the control group students got from the reading texts before and after the experiment $\left(\chi^{2}=2.53, \mathrm{sd}=2, \mathrm{p}<.05\right)$. There was no significant difference between the mean ranks for the pre-test (1.63), post-test (2.63), and follow-up test (1.75). The children in the control group who received the conventional instructional method did not differ statistically from the reading texts before and after the experiment. The effect size was calculated to identify whether the result found is significant (in practice). The medium and large effect sizes calculated for post-test-pre-test $(r=-0.57)$ and follow-up test-pretest $(r=-0.26)$ and follow-up test-posttest $(r=-0.46)$, are accounted for by the students' not progressing substantially in reading skills in the control group in the period between before and after the experiment.

The research results demonstrate that the experimental group students outperformed the control group in the reading comprehension questions regarding the texts after participating in RCIP. At the same time, we note that the students were able to define the content of the text and learn how this content was processed in the subject with the help of reading comprehension questions. In line with the study, the learning levels of students with mild mental disabilities and their social interactions with each other increased. 


\section{EKLER}

\section{Ek-1. Bir Uygulama Planı Örneği}

\section{METIN}

\section{BOZULAN TELEFON}

Fatma Öğretmen öğle vakti okuldan çıkmış, evine gidiyordu. Köy meydanından geçerken telefon kulübesinin başında birkaç çocuk gördü. Çocuklar telefonu kaldırıyor, kutuya vuruyorlardı. Fatma Öğretmen çocuklara:

-Çocuklar telefon ile oynamayın. Bu telefonları ihtiyacınız olduğunda kullanmalısınız, dedi.

Çocuklar telefonu bıraktılar. O sırada bir teyze telefon etmek için kulübeye geldi. Ancak telefon çalışmıyordu. Çocuğu çok hastaydı. Acil olarak şehirdeki hastaneye götürülmesi gerekiyordu.

Fatma Öğretmen kendi cep telefonu ile hastaneyi aradı. Çocuklar yaptıklarına pişman oldular. Bir daha insanların ortak kullandıkları mallara zarar vermeyeceklerine söz verdiler.

\section{SORULAR}

\section{(BOZULAN TELEFON)}

Yönerge: Okuduğunuz metin ile ilgili aşağıdaki soruların yanıtlarını söyleyiniz ve yazınız.

1. Metindeki olay ne zaman geçmektedir?

2. Metindeki olay nerede geçmektedir?

3. Metindeki olayda kimler bulunmaktadır?

4. Fatma Öğretmen ne yapıyordu?

5. Fatma Öğretmen evine giderken köy meydanında ne gördü?

6. Çocuklar ne yapıyorlardı?

7. Fatma Öğretmen çocuklardan ne yapmalarını istedi? 
8. Çocuklar telefonu birakınca ne oldu?

9. Fatma Öğretmen kendi cep telefonu ile hastaneyi niçin aradı?

10. Çocuklar neye söz verdiler?

\section{UYGULAMA PLANI -5}

DERS: Türkçe

SÜRE:90 dk.

GRUP: Hafif Düzeyde Zihinsel Yetersizliği Olan Öğrenciler (4 öğrenci, 2 kı_+2 erkek)

MEKÂN: Rehabilitasyon Merkezi'nin Drama Salonu

KONU: Okuduğunu Anlama

YÖNTEM VE TEKNIK: Yaratıcı Drama ( Doğaçlama, rol oynama, dramatizasyon)

ARAÇ-GEREÇ: Kalemler, silgiler, okuma metinleri, Türkçe Sözlük, farklı türde telefon fotoğrafları, Müzik: Cihat Aşkın, Minyatürler Albümü-12. Müzik.

\section{KAZANIMLAR:}

- Metni sesli okur.

- Metni sessiz okur.

- Metin içindeki anlamını bilmediği sözcükleri bulur.

- Metin içindeki anlamını bilmediği sözcüklerin anlamını söyler.

- Okuduğu metinle ilgili sorulara yanıt verir.

- İnsanların ortak kullandıkları eşyalara zarar verilmemesi gerektiğini fark eder.

\section{ATÖLYE İÇIN HAZIRLIKLAR:}

-İkinci etkinlik için duvara bir büyük kraft kağıdı asılır.

\section{A-HAZIRLIK-ISINMA}

1.Etkinlik: Lider, katılımcılara kendilerine birer minder alarak çemberde oturmalarını söyler. Liderin elinde üç tane fotoğraf vardır. Fotoğraflar; A4, beyaz kağıda basılmış bir cep telefonu, bir ev telefonu ve bir de ankesörlü telefon fotoğraflarıdır. (Seçilen fotoğraflar, çocukların 
günlük yaşamda tanıdıkları fotoğraflardır. Ankesörlü telefon hepsinin okulunda ya da mahallesinde mevcuttur.) Lider çemberde sağındaki katılımcıya birinci fotoğrafı (hangi fotoğraf olduğu önemli değildir.)verir. Katılımcı birinci fotoğrafı inceledikten sonra sağındaki katılımcıya fotoğrafı iletir. Birinci fotoğraf sağa doğru iletilmeye devam edilir. Sırayla herkes inceler. Çemberdeki ikinci kişi, birinci fotoğrafı incelerken, lider ikinci fotoğrafı dolaşıma çıkarır. Birinci ve ikinci fotoğraf incelenmeye devam edilirken, üçüncü fotoğraf da lider tarafından dolaşıma çıkarılır. Tüm fotoğraflar çemberde sırayla katılımcılar tarafından incelenir. Tüm fotoğraflar çemberde incelendikten sonra liderde toplanır.

Lider, gruba fotoğraflarla (telefon) ilgili aşağıdaki soruları sırayla yöneltir ve her katılımcıdan en az bir cevap almaya özen gösterir.

Lider:

-"Sizce telefon nedir?

-Sizce telefon ne işe yarar?

- Biraz önceki fotoğraflarda hangi çeşit telefonları gördük?

-Sizce cep telefonu nedir? / Ne işe yarar?

-Sizce ev telefonu nedir? / Ne işe yarar?

-Sizce ankesörlü telefon nedir? / Ne işe yarar?

- Günlük yaşamımızda hangi telefon çeşitlerini sık kullanıyoruz? Neden?

-Günlük yaşamımızda telefonun önemi nedir?”

sorularını sorar. Söz almak isteyen katılımcılar sorulara cevap verir.

\section{Etkinlik:}

Lider, az sonra bir müzik parçası açacă̆ını, müzik parçası çalarken serbest bir şekilde yürüyeceklerini ve müzik durduğunda bazı yönergelere göre hareket edilmesi gerektiğini belirtir. 
Lider, temposu düşük olan enstrümantal bir müzik parçası açar. Katılımcılar liderin yönergesiyle birlikte, mekânda, müzik eşliğinde, serbest bir şekilde yürür. Lider vereceği yönergelere katılımcıların uymalarını, yönergeleri yerine getirirken birbirleriyle el-kol temasında bulunmamalarını ve sözlü iletişim kurmamalarını belirtir.

*Lider her seferinde, yönergeyi verdikten sonra katılımcılarla birlikte verdiği yönergeye göre hareket ederek katılımcılara model olur.

Liderin yönergeleri:

-Müzik eşliğinde mekânda serbest bir şekilde yürüyelim.

Lider 30 sn. sonra müziği durdurur. Katılımcılar olduklarl yerde hiç kıpırdamadan/hareketsiz, konuşmadan/sözsüz dururlar. Lider yönergeyi verir.

-Evde koltukta otururken, ev telefonunuz çaldı. Anneniz arıyor. Ev telefonunuzu açıyorsunuz ve annenizle konuşmaya başlıyorsunuz.

Herkes ortalama bir dakika süreyle telefonda konuşur. Süre dolduğunda müzik başlar ve herkes serbest bir şekilde yürümeye devam eder.

-Müzik eşliğinde mekânda serbest bir şekilde yürüyelim.

Lider 30 sn. sonra müziği durdurur. Katılımcılar olduklarl yerde hiç kıpırdamadan/ hareketsiz, konuşmadan/sözsüz dururlar. Lider yönergeyi verir.

- Markette alış veriş yaparken, cep telefonunuz çaldı. Sınıf arkadaşlarınızdan biri arıyor. Cep telefonunuzu açıyorsunuz ve onunla konuşmaya başliyorsunuz. Herkes ortalama bir dakika süreyle telefonda konuşur. Süre dolduğunda müzik başlar ve herkes serbest bir şekilde yürümeye devam eder.

-Müzik eşliğinde mekânda serbest bir şekilde yürüyelim.

Lider 30 sn. sonra müziği durdurur. Katılımcılar olduklarl yerde hiç kıpırdamadan/ hareketsiz, konuşmadan/sözsüz dururlar. Lider yönergeyi verir. 
- Yolda yürürken; cep telefonunuz çaldı. Bir arkadaşınız sizi arıyor. Telefonunuzu açıyorsunuz ve arkadaşınızla konuşmaya başlıyorsunuz.

Herkes ortalama bir dakika süreyle telefonda konuşur. Süre dolduğunda müzik başlar ve herkes serbest bir şekilde yürümeye devam eder.

-Müzik eşliğinde mekânda serbest bir şekilde yürüyelim.

Lider 30 sn. sonra müziği durdurur. Katılımcılar olduklarl yerde hiç kıpırdamadan/ hareketsiz, konuşmadan/sözsüz dururlar. Lider yönergeyi verir.

-Yolda yürürken, üç çocuk gördünüz. Ankesörlü telefonu tekmeliyorlar. Telefon kırıldı. Ankesörlü telefon artık çalışmıyor. Gidip çocuklarla konuşmaya karar verdiniz. Çocukların yanına geldiniz.

Lider katılımcıların oldukları yerde hiç kıpırdamadan/ hareketsiz, konuşmadan/sözsüz durmalarını söyler.

Liderin dokunduğu kişi, çocuklara söylemek istediği cümlesini söyler.

Lider sirayla herkese dokunur ve herkesin cümlelerini söylemesine özen gösterir.

Lider herkesin cümlesini sırayla duvardaki kraft kağıdına yazar.

Etkinlik tamamlandıktan sonra çember formunda, minderlerle yere oturulur.

\section{ARA DEĞERLENDİRME}

Lider, gruba sorular yöneltir.

-Şimdiye kadar sırayla hangi etkinlikleri yaptık?

*Tüm yapılanlar grupla sırayla konuşulduktan sonra lider gruba ikinci soruyu yöneltir.

-Günlük yaşamımızda telefon bizim için önemli mi? Neden?

- Biraz önce çocukların ankesörlü telefona ne yaptıklarını gördük. Az önceki etkinlikte ankesörlü telefonu kıran çocuklara bir şeyler söylediniz. Söylediğimiz cümleler duvardaki kraft kağıdına yazılı. O söylediklerimizi de düşünelim. Sizce insanlar, ortak kullandıkları eşyalara nasil davranmalı? 


\section{CANLANDIRMA}

Etkinlik 3: Lider, katılımcılara çember olmalarını söyler. 1'den 2'ye kadar saymalarını ve 1'lerin ve 2'lerin birbirlerini bularak, mekânda istedikleri bir yere oturmalarını söyler.

Lider bundan sonraki grup çalışmalarında eşlerin değişmeyeceğini belirtir ve katılımcılara, bir metnin bir bölümü, bir kâğıt ve bir de Türkçe Sözlük dağıtılacağını söyler.

\section{METIN}

Fatma Öğretmen öğle vakti okuldan çıkmış, evine gidiyordu. Köy meydanından geçerken telefon kulübesinin başında birkaç çocuk gördü. Çocuklar telefonu kaldırıyor, kutuya vuruyorlardı. Fatma Öğretmen çocuklara:

“-Lütfen eşlerinize bu metni, sırayla, sesli olarak okuyunuz.

Tüm arkadaşlarınızın okumaları bitene kadar bekleyiniz.

- Lütfen (herkes) bu metni sessiz (içinizden) olarak okuyunuz.

Yine tüm arkadaşlarınızın okumaları bitene kadar bekleyiniz."der.

-Lider: ’Bu metinde geçen her sözcüğün anlamını bilmemiz gerekiyor. Bu nedenle lütfen okuduğunuz metinde eğer varsa, anlamını bilmediğiniz sözcüklerin altını çiziniz. -Anlamını bilmediğiniz sözcüklerin anlamlarını sözlükten bulup, açıklamasını önlerinizdeki kâğıtlara yazınız.

- Anlamını bilmediğiniz sözcüğün anlamını eşlerinize okuyunuz.” der.

(Lider her katılımcının yanına gider, açıklamaları tek tek dinleyerek, kontrol eder.)

Etkinlik 4: Lider, katılımcılardan gönüllü birine Fatma Öğretmen, diğerlerine de metinde bulunan çocuklar olarak rol verir. Lider:

"Fatma Öğretmen çocukların yanına geldiğinde; çocuklara ne söylemiş olabilir? Öğretmenle çocuklar arasında neler yaşanmış olabilir? Şimdi bu durumu canlandıracağız.” der. 
(Lider, gruba yapacakları doğaçlamalar konusunda sözel yardımda bulunur.) Grubun canlandırması izlenir.

(Canlandırmanın tıkandığı yerde lider bir aksesuar kullanarak role girer.)

\section{ARA DEĞERLENDİRME}

Lider, katılımcılara çember olmalarını söyler ve gruba sorular sorar.

-Olay ne zaman geçmektedir?

-Olay nerede geçmektedir?

-Olayda kimler vardı?

-Fatma Öğretmen orada ne yapıyordu?

-Fatma Öğretmen evine giderken ne gördü?

-Çocuklar ne yapıyorlardı?

-Yaptığınız canlandırmalardan da yola çıkarak, Fatma Öğretmen çocuklara ne söylemiş olabilir?

Etkinlik 5: Lider katılımcılara çember olmalarını söyler. Lider: "Lütfen eşlerinizi bulunuz. Sizlere metnin devamını dağıtılacak" der.

\section{METNIN DEVAMI}

- Çocuklar telefon ile oynamayın. Bu telefonları ihtiyacınız olduğunda kullanmalısınız, dedi.

Çocuklar telefonu bıraktılar. O sırada bir teyze telefon etmek için kulübeye geldi.

Ancak telefon çalışmıyordu. Çocuğu çok hastaydı. Acil olarak şehirdeki hastaneye götürülmesi gerekiyordu.

-Lütfen eşlerinize bu metni, sırayla, sesli olarak okuyunuz.

Tüm arkadaşlarınızın okumaları bitene kadar bekleyiniz. 
- Lütfen (herkes) bu metni sessiz (içinizden) olarak okuyunuz.

Yine tüm arkadaşlarınızın okumaları bitene kadar bekleyiniz.” der.

-Lider: "Metni anlamak için bu metinde geçen her sözcüğün anlamını bilmemiz gerekiyor. Bu nedenle lütfen okuduğunuz metinde (eğer varsa), anlamını bilmediğiniz sözcüklerin altını çiziniz.

-Anlamını bilmediğiniz sözcüklerin anlamlarını sözlükten bulup, açıklamasını önlerinizdeki kâğıtlara yazınız.

- Anlamını bilmediğiniz sözcüğün anlamını eşlerinize okuyunuz.” der.

(Lider her katılımıının yanına gider, açıklamaları tek tek dinleyerek, kontrol eder.)

Etkinlik 6: Lider, katılımcılara çember olmalarını söyler. Lider:

-Sizce teyzenin yüz ifadesi nasıldır?

-Fatma Öğretmen durumu öğrendiğinde ne düşünmüş olabilir?

-Çocuklar haberi duyunca ne düşünmüş olabilirler?

-Bu anı düşünüp, bu anı sesiz, sözsüz ve hareketsiz olarak canlandıracağız. Kendini hazır hisseden mekândaki yerini alabilir. Yanına gelip, dokunduğum kişi o anla ilgili bir cümle söyleyerek, tekrar sesiz, sözsüz ve hareketsiz kalabilir” der.

Lider sahneye gelerek donan her katılımcıya dokunur ve imgesiyle ilgili cümlesini söylemesini ister.

Etkinlik 7: Lider herkesin bir anda canlanmasını ve hep birlikte o anı canlandırmalarını söyler.

Doğaçlama: Teyzenin “Lütfen yardım edin. Telefon çalışmıyor” cümlesiyle başlayacaktır.

Lider, katılımcılarla yapılan canlandırmanın değerlendirmesini yapar.

Etkinlik 8: Lider katılımcılara çember olmalarını söyler ve metnin sonunda ne olmuş olabileceğini katılımcılara sorar.

Lider katılımcıların görüşlerini aldıktan sonra; metnin sonunu okumaları için herkese metnin sonu dağıtılır. 


\section{METNIN DEVAMI}

Fatma Öğretmen kendi cep telefonu ile hastaneyi aradı. Çocuklar yaptıklarına pişman oldular. Bir daha insanların ortak kullandıkları mallara zarar vermeyeceklerine söz verdiler.

\section{Lider:}

-Lütfen (herkes) bu metni sesli olarak okuyunuz.

Tüm arkadaşlarınızın okumaları bitene kadar bekleyiniz.

-Şimdi de sessiz (içinden) olarak okuyunuz.

Yine tüm arkadaşlarınızın okumaları bitene kadar bekleyiniz” der.

-Lider, metinden çıkan sonuç ile kendi görüşleri arasındaki benzerlik ya da farklılıkları karşılaştırmalarını söyler.

\section{DEĞERLENDİRME}

Lider, katılımcilara:

“- Çocuklar telefonu kırınca ne oldu?

- Fatma Öğretmen kendi cep telefonu ile hastaneyi niçin aradı?

- Çocuklar neye dair söz verdiler?

- Sizce bu gün ne öğrendiniz?

- Bu metne bir başlık koymak isterseniz, ne koyardınız? Neden?”

- Bu günkü çalışmayı değerlendirseniz ne söyler siniz? Sorularını sorar.

*Lider her soruda herkesten tek tek cevap almaya özen gösterir. 


\section{YAYIN ETİĞİ BEYANI}

$\mathrm{Bu}$ araştırmanın planlanmasından, uygulanmasına, verilerin toplanmasından verilerin analizine kadar olan tüm süreçte "Yükseköğretim Kurumları Bilimsel Araştırma ve Yayın Etiği Yönergesi” kapsamında uyulması belirtilen tüm kurallara uyulmuştur. Yönergenin ikinci bölümü olan "Bilimsel Araştırma ve Yayın Etiğine Aykırı Eylemler" başlığg altında belirtilen eylemlerden hiçbiri gerçekleştirilmemiştir. Bu araştırmanın yazım sürecinde bilimsel, etik ve alıntı kurallarına uyulmuş; toplanan veriler üzerinde herhangi bir tahrifat yapılmamıştır. $\mathrm{Bu}$ çalışma herhangi başka bir akademik yayın ortamına değerlendirme için gönderilmemiştir.

\section{ARAŞTIRMACILARIN KATKI ORANI BEYANI}

Tüm araştırma süreci birinci yazar tarafından ikinci ve üçüncü yazar danışmanlığında gerçekleşmiştir.

\section{DESTEK VE TEŞEKKÜR}

Bu araştırma 2017 yılında ikinci ve üçüncü yazarın danışmanlıklarında hazırlanan birinci yazarın yüksek lisans tezinden üretilmiştir. 30. Ulusal Özel Eğitim Kongresi’nde sözlü bildiri olarak sunulmuştur. Araştırmaya katılan tüm katılımcılara teşekkürlerimizi sunarız.

\section{ÇATIŞMA BEYANI}

Araştırmanın yazarları olarak herhangi bir çıkar/çatışma beyanımız olmadığını ifade ederiz. 